\title{
Okul öncesi dönem çocuklarının meslek algıları ve geleceğe dönük mesleki hayalleri
}

\section{Preschool children's occupational perceptions and dreams}

\author{
Makale Geçmişi \\ Geliş : 11 Mayıs 2020 \\ Düzeltme : 25 Ağustos 2020 \\ Kabul : 2 Mayis 2021
}

\section{Makale Türü}

Araştırma Makalesi

\section{Article History}

Received : 11 May 2020

Revised : 25 August 2020

Accepted : 2 May 2021

Article Type

Research Article

\author{
Yemliha Coşkun ${ }^{1}$, Ahmet Önem ${ }^{2}$
}

Öz: Bu araştırmanın amacı, okul öncesi dönem çocuklarının mesleklere yönelik algılarını belirlemektir. Bu bağlamda çocukların meslek kavramına, meslek sahibi olmaya, anne ve babasının mesleğine, büyüdüğünde yapmak istediği mesleğe ve bu mesleği seçme nedenine yönelik görüşleri sorgulanmiştır. Ayrıca çocukların görselde yer alan kişilerin mesleğinin ne olduğu ve yaptığ1 mesleki faaliyetleri konusundaki düşünceleri belirlenmiştir. Araştırmada nitel araştırma yöntemlerinden olgu bilim kullanılmıştır. Araştırma 2019-2020 eğitim-öğretim yılı birinci döneminde gerçekleştirilmiştir. Araştırmaya basit seçkisiz örneklem yoluyla 8 ayrı okulda okul öncesi eğitime devam eden 5 yaş grubundaki $22 \mathrm{kız}$ ve 20 erkek olmak üzere toplam 42 çocuk katılmıştır. Araştırmanın verileri yarı yapılandırılmış görüşme formu ve mesleklere ilişkin görsellerin bulunduğu slaytlar kullanılarak toplanmıştır. Araştırma sonucunda çocukların görseldeki kişinin hangi mesleği yaptığını bilmemelerine ya da farklı cevaplar vermelerine rağmen yaptığı işlerle ilgili fikir ve bilgi sahibi oldukları, yaptığı işi anlamlandırdıkları ve algıladıkları, görseldeki kişinin hangi mesleği yaptığını bilen çocukların o kişinin yaptığ işlere örnek verdikleri, açıkladıkları ve nitelendirdikleri görülmüştür.

Anahtar Kelimeler: Okul öncesi dönem, Mesleki gelişim, Mesleki rehberlik

Abstract: The purpose of this study is to examine the perceptions of preschool children towards professions. In this context, please to the concept of profession, to have a profession, to the profession of his mother and father, to the profession he wants to do and to choose this profession. In addition, to examine what is the occupation of the issues in the visual and the reason for it. Case study of qualitative research methods in the research. The research was carried out in the first semester of the 2019-2020 academic year. A total of 42 children, 22 girls and 20 boys in the 5-year age group, who continue preschool education in 8 different schools, have been folded through the simple random sampling. The graphics of the research were collected for slides in semi-structured interview forms and visuals by professions. For research purposes, you should not know how you use it visually or give different answers.

Keywords: Preschool period, Professional development, Vocational guidance 


\section{SUMMARY}

\section{Introduction}

As an inevitable phenomenon of life, every person has some professional tendencies and preferences, and the decisions in this regard significantly affect people's living standards in terms of psychological, social, economic, cultural and health dimensions. Individuals start to develop ideas about the concept "profession" and the professions based on the knowledge they have acquired from the early stages of their lives, their interest in and curiosity about professions increase, and the first observations and experiences about professional matters emerge in this period. When children are asked about what professions they want to pursue when they grow up, they usually respond with some profession names or concepts related to professions. They mention about the occupational groups that are more common in society or considered relatively more important in their sociocultural environment. In order to make the right decisions in their career choices in the future, it is very important for children to be informed about different professions as much as possible. So, evaluating children's perceptions, knowledge, thoughts and dreams about professions with an analytical approach in the early professional development period will make the education and guidance services more functional. Moreover, understanding whether the reality of life overlaps with the profession will also contribute to the efforts in this regard. In professional terms, the behaviors expected from individuals in every age period constitute the professional development task specific to that age. While imagining professions and representing the desired professions in games in childhood are a development task specific to that age; in adolescence, being aware of own interests and abilities constitutes a development task. So, an individual's professional development includes the development stages starting from the emergence of an idea about profession in childhood to having a profession in adulthood (Kuzgun, 1999; Yeşilyaprak, 2000). However, individuals' inability to acquire as much information as necessary about professions in this period of time may cause negative consequences in the following years (Temel et al., 2018). Therefore, efforts should be made starting from the preschool period to ensure that children develop a positive attitude based on correct information rather than stereotypes about professions (Ministry of National Education, 2012). In other words, children's education designed to fulfill their professional development tasks should start from the preschool period and they should be guided according to their personal abilities and competencies (Vurucu, 2010). Within this context, the following questions were addressed in order to determine the preschool children's occupational perceptions and dreams: What are the children's opinions about the concept of profession? What are the children's opinions about having a profession? What are the children's opinions about their parents' profession? What are the children's opinions about the profession they want to pursue when they grow up and the reasons for choosing that profession? What are the children's opinions about the profession of the person in a picture and what the people from that profession do? 


\section{Method}

This study was designed as phenomenology, one of the qualitative research methods. Simple random sampling method was used to select the study group. The study was carried out with the participation of 42 children, 22 girls and 20 boys, at the age of 5, who were studying in public kindergartens in the city center of Kahramanmaraş. Semi-structured interview form and some visuals about professions were used as data collection tools in the study. The children's opinions about judges, psychologists, engineers, academicians, and YouTubers were received by asking questions without showing any visuals. Content analysis technique was used to analyze the data.

\section{Results}

It was observed that nothing came to the minds of almost half of the children about the concept of profession, while the rest of them mentioned about concepts such as job, occupational groups, family, school, and playing games. The majority of the children expressed that everyone should have a profession. Most of the children stated that their mothers had a profession and they saw the housework done by their mothers as a profession. Again, it was observed that almost all the children knew that their fathers had a profession, such as worker, teacher, wall painter, and mechanic. On the other hand, some of the children who stated that their fathers had a profession did not know what their father's profession was. Another result of the study was that the children stated that they wanted to be a doctor, teacher, and policemen the most when children grow up. When the results of the study are evaluated overall, the professions that the children knew and named the most were as follows: teacher, doctor, soldier, policewoman/policeman, firewoman/fireman, garbage collector, hairdresser, mechanic, and grocery store owner. On the other hand, the professions they knew and named the least were as follows: veterinarian, butcher, locomotive driver, pilot, ship's captain, tailor, waiter, imam, football player, driver, astronaut, pharmacist, and newswoman/newsman. The professions that the children partially knew and named were as follows: nurse, cook, construction worker, and singer. On the other hand, it was observed that the children did not have sufficient knowledge and awareness about the professions such as judge, psychologist, engineer, and academician.

\section{Conclusion and Discussion}

As a result of the study, it was found that most of the children did not have an idea about the concept "profession", and some of them explained it with the concepts such as job, occupational groups, family, school, and playing games. Although they showed an insufficient development in this regard, the majority of the children stated that everyone should have a profession. However, the children who said that everyone should have a profession did not know why people should have a profession, and they put forward some explanations such as earning money, going to school, and having to have a job. It may be asserted that the children's knowledge about professions was generally related to the professions that they have more interaction with in their daily lives, they have more life experiences about, or they encounter more frequently. In addition, cartoons and other media might have contributed to the children's thoughts and awareness 
about professions. However, it was observed that the children did not know and name some professions, and this might be due to their socioeconomic conditions and insufficient development. So, introducing professions to children and informing them about the works/services provided by each profession starting from the preschool period will be very beneficial in terms of developing professional awareness in them and enabling them to make a correct choice of profession, which is an important issue in the lives of individuals. 


\section{GİRIŞ}

Hayatın kaçınılmaz bir olgusu olarak her insanın bir mesleki yöneliminin olması gerekliliği ve bu yöndeki tercihler, insanın psikolojik, sosyal, ekonomik, kültürel ve sağllk boyutlarıyla yaşam standartlarını etkileyecek oldukça önemli bir karardır. Bireylerin erken yaşlardan itibaren edindikleri bilgi çerçevesinde meslek kavramına ve mesleklere yönelik düşünceler geliştirmeye başladıkları, ilgi ve meraklarının arttığı görülmekte, mesleki konularda ilk gözlem ve deneyimleri bu süreçte ortaya çıkmaktadır. Büyüdüklerinde yapmak istedikleri mesleklerle ilgili çocuklara sorular yöneltildiğinde genelde meslek adlarıla ya da mesleklerle ilgili kavramlarla cevap verdikleri, özellikle toplumda daha sık karşılaşılan, ya da bulundukları sosyokültürel ortamda göreceli olarak daha önemli görülen meslek gruplarından söz ettikleri görülmektedir. Oysaki, çocukların olabildiğince farklı meslekler hakkında bilgi sahibi olmaları, ilerde seçenekleri değerlendirip meslek tercihlerinde doğru karar vermelerinde yararlı olacaktır. Bu doğrultuda erken dönemlerden başlayan mesleki gelişim sürecinde çocukların meslek kavramı ve mesleklere ilişkin algı, bilgi, düşünce ve hayallerinin analitik bir yaklaşımla değerlendirilmesi, hayatın gerçekliği ve meslek olgusunun gerekirlikleriyle örtüşüp örtüşmediğinin anlaşılması, çocukluktan itibaren verilecek eğitim ve yönlendirme hizmetlerini daha işlevsel hale getirecektir.

Bireyin yaşamını sürdürebilmesi için aldığı eğitim, gösterdiği çaba, sahip olduğu deneyim ve beceriye dayalı iş olarak tanımlanabilen (Kunduracılar vd., 2012) meslek, insanın çalışması sonucunda maddi gelir elde etmesini sağlayan, toplumdaki konumunu belirleyen, hukuki ve ahlaki kurallardan oluşan bir ekonomik etkinlik biçimidir (Arslan vd., 2017). Toplumda her bireyin, başkalarının işine yarayacak ürün ve hizmet üretmesi ve onlardan işine yarayacak olanları alması, meslek dediğimiz faaliyet alanının gelişmesi ile gerçekleşebilmektedir (Kuzgun, 1999). Meslek, ekonomik bir etkinlik olarak, insan yaşamının en az üçte birlik bir sürecini kapsayacak bir zaman birimi içinde sürdürülen faaliyetleri içermektedir. Bu durum meslek seçiminde bireylerin erken yaşlardan itibaren yönlendirilmesinin, rehberlik edilmesinin önemini ortaya çıkarmakta olup, iş arama döneminde yapılacak yardımın artık geç kalınmış, etkisi yetersiz bir yardım olacağı değerlendirilmektedir (Kuzgun, 1999).

Meslek seçimi insanların yaşamları boyunca verdiği önemli kararlardan bir tanesidir (Bozgeyikli, 2008; Çakır, 2004) ve bu seçimde aile, medya, akademik başarı, arkadaş, kültür, gelir seviyesi, istihdam firsatları, mesleğin sosyal kabul edilebilirliği, iş tatmini gibi birçok faktör etkili olmaktadır (Kazi ve Akhlaq, 2017). Meslek seçimi bireyin meslekleri inceleyip, araştırarak farklı yönlerini değerlendirmesi ve gereksinimlerini göz önüne alarak kendisine uygun olan bir mesleğe eğilim duymasıdır (Yeşilyaprak, 1986). Bireyin bu seçimi yaşamını nasıl sürdüreceğini, nasıl bir çevreye sahip olacağını, iletişim kuracağı kişileri, değerlerini, düşüncelerini, duygularını, isteklerini, 
ekonomik durumunu ve işini severek yapıp yapmamasını etkileyen bir durum olduğu için (Hamamcı vd., 2013; Pekkaya ve Çolak, 2013; Tuzcuoğlu, 2000; Ulaş vd., 2017) bireyin meslek seçiminin rastlantıdan uzak ve özenli bir biçimde olması gerekmektedir (Doğan ve Kuzgun, 2008). Aksi durumda kendi beceri, ilgi ve yatkınlığının farkında olmadan çeşitli sebeplerden dolayı meslek seçimine yönelik verecekleri kararın bireyin kendisi ve yaşadığ1 toplum için doğuracağı sonuçlar farklı olacaktır (Erkalan vd., 2012).

Mesleklere duyulan ilgi, beceri, düşünce ve duygular yaşam içinde şekillenmekte ve oluşmaktadır. Belirli gelişim aşamalarından geçerek mesleklere ilişkin kazanımlar elde edilmektedir. Bu süreç mesleki gelişim olarak ele alınmaktadır. Mesleki anlamda her yaş döneminde bireylerden beklenen davranışlar o yaşa özgü mesleki gelişim görevini oluşturur. Çocukluk döneminde meslekleri hayal etmek, özenilen meslekleri oyunlarda temsil etmek o yaşa özgü gelişim görevi iken, ergenlikte ise ilgilerin ve yeteneklerin farkına varmak gelişim görevini oluşturur. Bu anlamda mesleki gelişim, bireyin çocukluğunda bir meslek düşüncesinin ortaya çıkmasından başlayarak yetişkinliğinde bir meslek sahibi olmasına değin geçen gelişim aşamalarını içermektedir (Kuzgun, 1999; Yeşilyaprak, 2000). Mesleki gelişimi, Özellik-Faktör, Psikanalitik Kuramlar, Roe’nun İhtiyaç Kuramı, Holland'ın Kişilik Kuramı, Karar Kuramları gibi farklı kuramlar açıklamaya çalışmakla birlikte Gelişim kuramcılarından Ginzberg ve arkadaşları mesleki gelişimi bir gelişim süreci olarak ele almış meslek seçimine yönelik verilen kararın yaşamın ilk yirmi-yirmi iki yılında gerçekleşmekte olduğunu belirtmişlerdir. Mesleki gelişim sürecini hayal, deneme ve gerçeklik dönemi olarak üçe ayırmaktadırlar. Hayal dönemi, 6-11 yaş aralığında çocukluk yıllarını kapsamaktadır. Çocuklar, küçük yaşlardan itibaren meslek seçimi için açık bir biçimde düşüncelerini belirtirler ve hoşlandıkları mesleklere yönelirler. Hayal döneminin sonuna doğru çevresinden etkilenmeler başlarken, oynadıkları oyunlar yoluyla da diğer aşamalardaki meslek seçimine hazırlanmakta oldukları belirtilmiştir (Kuzgun, 2000; Kuzgun, 2002). Diğer bir gelişim kuramcısı Super ise, bireylerdeki mesleki gelişimi yaşamın sonuna değin süren evreler şeklinde incelemiştir. Bu evreler büyüme, araştırma, yerleşme, devam ettirme ve çöküntü dönemidir. Büyüme dönemi hayal, ilgi ve yetenek aşamalarından oluşmaktadır. Super, çocukların 4-10 yaş arasında hayal aşamasında olduğunu ve bu aşamada hayal kurduklarını ve mesleki rollere girdiklerini, davranışların anlık gereksinimlere ve gelip geçici isteklere göre değişmekte olduğunu belirtmiştir (Kuzgun, 2000).

Farklı kuramlara göre analiz yapılması mümkün olmakla birlikte mesleki gelişimi, okul öncesi dönemde ortaya çıkan ve yaşamın sonuna değin devam eden bir süreç olduğu bakış açısına göre (Hamamcı ve Esen Çoban, 2007; Yılmaz Erdem ve Bilge, 2008;) değerlendirdiğimizde kimi insanların, çocukluktan itibaren çalışmak istediği mesleğe yönelik düşünceler geliştirdiklerini (Razon, 1983) zaman içerisinde karşılaştı̆̆1 mesleklerin de bıraktığ1 etkiyle kendilerine uygun 
buldukları mesleğe yönelmekte oldukları görülmektedir (Demir vd., 2011). Ancak bu süreçte bireylerin mesleklerle ilgili yeterli bilgi edinememesi hali, ilerleyen yllarda olumsuz sonuçlar doğurabilmektedir (Temel vd., 2018). Bu anlamda okul öncesi dönemden itibaren çocukların mesleklere ilişkin yerleşmiş kalıp düşünceler yerine, doğru bilgiye dayalı bir tutum geliştirmeleri için çaba gösterilmelidir (Millî Eğitim Bakanlığ1, 2012). Okul öncesi dönemde düşünceler duygusal ve hayali bir biçimdedir (Çakmak, 1992). Dolayısıyla çocuklar bu dönemde gerçekçi olmadıklarından dolayı meslekler konusunda yapılacak bilgilendirilmelerin ayrıntıdan uzak genel bir çerçevede sunulması, çocukların yakın çevresindeki mesleklerin ön plana alınması ve bu kişilerin yaptıkları işlerin neler olduğunun açıklanması önem kazanmaktadır (Özgüven, 2001). Bu sayede çocuklar mesleklere ve kişilerin yaptıkları işlere ilişkin düşünce sahibi olmakta ve bunları günlük yaşamlarında kullanabilmektedirler. Bunu da en iyi şekilde oyunlarında göstermektedirler. Okul öncesi dönemde çocuklar oyun oynarken kendilerini başkalarının yerine koyarlar. Anne, baba, doktor, polis, öğretmen gibi rollere girerler. Doktor olur hastaları iyileştirir, polis olur suçluları yakalar, kendi anne, babasının davranışları gibi davranışlar gösterirler (Yörükoğlu, 1998). Bu anlamda, mesleki gelişimleri açısından çocukların oyunlarında ve günlük yaşamlarında gösterdikleri davranışların yapılacak yöneltme çalışmalarıyla desteklenmesi önem taşımaktadır. Çocukların yeteneklerinin ve ilgi alanlarının keşfedilmesi, onların yeni deneyimleri ve bilgileri kazanmasını sağlayacak eğitici etkinlikler yoluyla gerçekleştirilebilir. Bunun için mesleklere yönelik oyun, şarkı, tekerleme, dans, gezi, gözlem, hikâye gibi etkinliklere yer verilmeli (Özgüven, 2001; Schultheiss, Palma ve Manzi, 2005), yani çocukların mesleki gelişim görevlerini yerine getirmelerinde, eğitimlerine okul öncesi dönemden başlanarak, kişisel yetenek ve yeterliliklerine göre yönlendirme yapılmalıdır (Vurucu, 2010).

Okul öncesi dönemde çocukların mesleklere yönelik farkındalık kazanmaları, meslekler konusunda bilgi sahibi olmaları, meslek sahibi olan kişilerin yaptıkları işlerin neler olduğunu bilmelerinin yanı sıra kendi ilgi ve yetenekleri konusunda bilinçlenmelerini sağlamak için gerçekleştirilecek rehberlik hizmetleri, eğitim faaliyetlerinin amaca uygun, somut hedeflere ulaşma konusundaki verimliliğini arttırıcı olacaktır. Dolayısıyla eğitimin meslek kazandırma istendik hedeflerine ulaşılmasında emek ve zaman kaybının en aza indirilmesinde bireylerin mesleki algılarının, düşüncelerinin olabildiğince erken yaşlarda olgunlaşmaya başlayarak farkındalıklarının artması, çocukların mesleki gelişimleri açısından oldukça önemli olmakla birlikte, eğitimin hedeflerinin gerçekleştirilmesi çabasında eğitim programlarının planlanmasının daha rasyonel kılınması açısından da önemlidir. Bu anlamda alanyazın incelediğinde farklı çalışmaların yapıldığı görülmektedir. Barclay (1974) okul öncesi çocukların mesleki beklentilerini, Güler ve Akman (2006) altı yaş çocuklarının bilim ve bilim insanı hakkındaki görüşlerini, Ceylan vd. (2009) altı yaş çocuklarının mimarlık mesleği ile ilgili görüşlerini, 
Lee (2012) Tayvanlı okul öncesi çocukların büyüdüklerinde yapmak istedikleri mesleklere ilişkin görüşlerini, Pehlivan ve Gökbulut (2015) drama yöntemi ile okul öncesi dönem çocuklarına mesleklerin tanıtılmasını, Ayvacı vd. (2016) okul öncesi çocukların bilim insanı kavramına yönelik algılarını incelemişlerdir. Genç ve Alkan Ersoy (2016) 6 yaş çocuklarının gelecekte olmak istedikleri mesleklerin neler olduğunu ve neden bu meslekleri seçtiklerini, Karabekmez vd. (2018) okul öncesi dönemde çocukların mesleklere yönelik toplumsal cinsiyet algılarını, Alabay ve Özdemir (2020) 3672 aylık çocukların mesleklere ilişkin oluşturdukları toplumsal cinsiyet algılarını, Temiz vd. (2020) 5 yaş çocuklarının yapmak istedikleri mesleğe ilişkin görüşlerini incelediği görülmüştür. Yapılan çalışmaların belirlenmiş bir mesleğe yönelik çocukların görüşleri ya da çocukların gelecekte yapmak istedikleri mesleğe ilişkin görüşlerine yönelik olduğu görülmektedir. Bu bağlamda alana katkı sağlayacağı düşünülen bu çalışmanın da okul öncesi dönem çocuklarının mesleklere yönelik ilgilerinin, meslekleri tanımalarına ve isimlendirmelerine yönelik bilgilerinin, meslek gruplarının yaptıkları işler ve meslek sahibi olmanın gerekliliği hakkındaki düşüncelerinin ve yapmak istedikleri mesleklerin neler olduğuna ilişkin görüşlerinin belirlenmesi, çocukların bu yaştaki mesleki gelişimlerini ve farkındalıklarını anlama adına yarar sağlayacağı düşünülmektedir. Bu doğrultuda araştırmanın amacı, okul öncesi dönem çocuklarının meslek algılarını ve geleceğe dönük mesleki hayallerini belirlemektir. Bu genel amaç doğrultusunda, araştırmanın alt amaçları şu şekilde oluşturulmuştur;

1) Çocukların meslek kavramına yönelik görüşleri nelerdir?

2) Çocukların, insanların meslek sahibi olmalarına yönelik görüşleri nelerdir?

3) Çocukların, anne ve babasının mesleğine yönelik görüşleri nelerdir?

4) Çocukların büyüdüklerinde sahip olmak istedikleri mesleğe ve bu mesleği seçme nedenlerine yönelik görüşleri nelerdir?

5) Çocukların resimde yer alan kişinin yaptı̆̆1 mesleğe ve bu mesleğe sahip kişilerin ne iş yaptıklarına yönelik görüşleri nelerdir?

\section{YÖNTEM}

\section{Araştırmanın Modeli}

Araştırmada nitel araştırma yöntemlerinden olgu bilim kullanılmıştır. Olgu bilim bireylerin bir olguya ilişkin deneyimlerinin araştırılarak (Onat Kocabıyık, 2016), olgunun daha iyi anlaşılmasını ve bilinmesini sağlayacak bir süreci kapsamaktadır. Bu olgular yaşantının içinde olmakla birlikte yeterli bilgimizin olmadığı durumlardan oluştuğu için olgu bilim kullanılmaktadır (Yıldırım ve Şimşek, 2016). 


\section{Çalı̧̧ma Grubu}

Çalışma grubunu, Kahramanmaraş merkezinde yer alan devlet anaokullarında öğrenim görmekte olan 5 yaş grubundaki 42 çocuk oluşturmuştur. Çocukların 22'si kız, 20'si ise erkektir. Çalışmaya katılan çocuklar basit seçkisiz örneklem yoluyla seçilmiştir. Bu anlamda basit seçkisiz örneklem, çalışmaya bağımsız ve eşit bir biçimde katılım olasılığı sunmuştur (Best ve Kahn, 2017).

\section{Veri Toplama Arac1}

Araştırmada veri toplama aracı olarak yarı yapılandırılmış görüşme formu ve mesleklere ait görseller kullanılmıştır. Araştırmacılar tarafindan hazırlanan görüşme formu açık uçlu 6 sorudan oluşmaktadır. Ayrıca görüşme formuna ek olarak meslek görselleriyle ilgili çocuklara sorular sorulmuştur. Meslek görselleri; öğretmen, doktor, asker, polis, hemşire, itfaiyeci, veteriner, çöpçü, şarkıcı, kasap, aşçı, makinist, pilot, gemi kaptanı, kuaför, terzi, garson, inşaat işçisi, tamirci, imam, futbolcu, astronot, eczac1, bakkal, spiker olarak yer almıştır. Hâkim, psikolog, mühendis, akademisyen ve YouTuber meslekleri hakkında ise görsel olmadan soru sorularak görüşleri alınmıştır. Bu meslekler seçilirken çocukların gelişim seviyeleri, ilgi ve mesleklerle günlük yaşamda karşılaşılma sıklığı belirleyici olmuştur. Olgu bilimde veri toplama aracı olarak görüşme yönteminin kullanılması daha uygundur (Wimpenny, 2000). Yarı yapılandırılmış görüşmeler ise soruların sırasını değiştirmeye, soruları esnek bir biçimde uygun bir dil kullanarak ifade etmeye ve açıklamaya imkân vermektedir. Bunun yanı sıra katılımcıların konuyla ilgili düşüncelerini, tutumlarını, inançlarını öğrenmek için önceden hazırlanmış sorulardan oluşmaktadır (Berg ve Lune, 2015). Görüşme soruları ve slaytlarda yer alan görsellerle ilgili iki uzmandan görüş alınmıştır. Çalışma öncelikle biri kız ve diğeri erkek iki çocukla pilot çalışma şeklinde yapılmıştır. Çocukların anlama problemi çektikleri düşünülen slaytlar ve ifadeler uzman görüşleri doğrultusunda düzeltildikten sonra verilerin toplanmasına başlanılmıştır. Araştırmanın etik kurallar açısından uygunluğu ve yapılabilirliği ile ilgili, üniversite etik kurulunun onayı bulunmaktadır. Görüşme formunda aşağıdaki sorulara yer verilmiştir;

1) Meslek deyince aklına ne geliyor?

2) Herkesin bir mesleği olmalı mı? Niçin olmalı?

3) Annenin bir mesleği var m1, söyler misin?

4) Babanın bir mesleği var m1, söyler misin?

5) Büyüdüğünde yapmak istediğin mesleği söyler misin?

6) Neden bu mesleği yapmak istersin?

7) 'Resimde gördüğün kişi hangi mesleği yapmaktadır?’ (Sorular bilgisayar ekranındaki slaytları göstermek suretiyle sorulmuştur) sorusu sorulmuş, çocuk soruya doğru cevap verdiğinde mesleğin 
ismi tekrar söylenerek bu meslekteki kişinin ne iş yaptığ sorulmuştur. Örneğin 'Öğretmen ne iş yapar?’ gibi. Eğer meslek adı olarak doğru cevap verilmemişse, adını bilmese de yaptığı iş hakkında bilgisinin olup olmadığını anlama adına 'Resimdeki kişi ne iş yapmaktadır?' sorusu sorulmuştur. Doktor, asker, polis, hemşire, itfaiyeci, veteriner, çöpçü, şarkıc1, kasap, aşçı, makinist, pilot, gemi kaptanı, kuaför, terzi, garson, inşaat işçisi, tamirci, imam, futbolcu, şoför, astronot, eczacı, bakkal, spiker meslekleri için aynı şekilde sorular yöneltilmiştir. Ancak Hâkim, psikolog, mühendis, akademisyen ve YouTuber mesleklerine ilişkin resimlerin bariz temsil özelliğinin olmayıșı, yani başka yakın mesleklerle karıştırılma yanılgısına karşı ve de aynı zamanda çocukların somut resimleri görmeden de özellikle bu meslekler hakkındaki düşüncelerinin anlaşılması adına herhangi bir hatırlatıcı resim olmadan sorular sadece sözlü olarak yöneltilmiştir. Bu sorular "Hâkim ne iş yapar?”, "Psikolog ne iş yapar?”, “Mühendis ne iş yapar?”, “Akademisyen ne iş yapar?”, "YouTuber ne iş yapar?” biçimindedir.

\section{Verilerin Toplanması ve Analizi}

2019-2020 eğitim-öğretim yılı ilk döneminde okullara gidilerek çalışma gerçekleştirilmiştir. Araştırma ile ilgili veriler 8 haftada toplanmıştır. Yapılan görüşmeler yirmi-yirmi beş dakika sürmüştür. Çocuklara açık uçlu 6 soru sorulduktan sonra slayt olarak hazırlanmış mesleklere ilişkin görüntüler bilgisayardan gösterilmiştir. 'Şimdi sana mesleklerle ilgili bazı resimler göstereceğim. Bu gösterdiğim resimdeki kişilerin ne iş yaptığını bana söyler misin?’ denilerek resimler çocuklara gösterilmiştir. Slaytların her birini gösterdikten sonra 'Resimde gördüğün kişi hangi mesleği yapmaktadır?' ve devamında verilen cevap doğrultusunda 'Resimdeki kişi ne iş yapmaktadır?' sorusu sorulmuştur. Meslek görselleri olmayan hâkim, psikolog, mühendis, akademisyen ve YouTuber meslek gruplarının sorusu bu meslek gruplarına ilişkin standart resimlerin çok yaygın olmayışından ve çocukların özellikle bu dört mesleğe ilişkin ne ölçüde bilgiye sahip olduklarının herhangi bir hatırlatıcı resim olmadan belirlenmesi amacıyla sadece sözlü olarak yöneltilmiştir. Görüşme yapılan çocuklar gönüllülük esasına göre seçilmiştir. Çocukların duygu durumları göz önüne alınarak görüşme esnasında kendilerini rahat bir şekilde ifade etmesi için uygun ortam hazırlanarak konuyla ilgili bilgileri, düşünceleri, tahminleri belirlenmeye çalışılmıştır. Araştırmacılar sorular ve resimler ile ilgili kendi düşüncelerini görüşme boyunca paylaşmamışlar (Best ve Kahn, 2017) çocukların verdikleri cevaplar araştırmanın inandırıcıllğ̆ ve tutarlılığ sağlaması açısından değiştirilmeden kaydedilmiş ve tabloların altında doğrudan alıntılar biçiminde sunulmuştur. Ayrıca verilerin toplanma ve analiz süreci ayrıntılarıyla açıklanarak doğrulanabilirlik elde edilmiştir. Araştırmacı, aynı kişiyle birden fazla kez veya uzun bir süre görüşerek veya gözlemleyerek uzun süreli bir katılım sağlayabilir (Byrne, 2001). Bu çalışmada uzun süreli etkileşimin sağlanması amacıyla çalışmaya katılan çocukların sınıflarında bulunulmuş ve ardından sessiz bir ortamda çocuklarla görüşmeler 
gerçekleştirilmiştir. Çocuklara eğer görüşmeye devam etmek istemezlerse bırakabilecekleri, verdikleri cevapların doğru ve yanlış olarak değerlendirilmeyeceği belirtilerek kendilerini güvende hissetmeleri sağlanmıştır. Çocuklar katılım göstermesi için zorlanmamıştır. Görüşme boyunca sağlıklı bir iletişim kurulmaya çalışılarak, çocukların verdikleri cevapların anlaşılırlığ adına tekrarlanarak teyit edilmiştir. Katılımcı teyidi, genel çalışma içinde katılımcı bir çerçeve geliştirmeyi oldukça destekleyen ve katılımcı ile araştırmacı arasında anlaşılıllığı teşvik etmektedir (Doyle, 2007). Güvenirliği sağlamanın bir diğer yolu da tarafsızlığı sağlayabilmektir. Guba (1981) araştırmanın tarafsızlığının nesnellikle sağlanacağını bunun için de kullanılan yöntemlerin açıklanması, araştırmanın incelemeye açık ve tekrarlanabilir olması ve araştırmacının ön yargısız bir şekilde süreci yürütmesi gerektiğini ifade etmiştir. Dolayısıyla nesnel araştırmacı bilimsel olarak mesafeli, yani çalışmayı etkilemeyen ve çalışmadan etkilenmeyen biridir (Krefting, 1991). Araştırma gizliliğe ve etik ilkelere uygun olarak gerçekleştirilmiştir. Güvenirliği sağlamak adına araştırmacılar süreci açıklamalar doğrultusunda olabildiğince tarafsız bir şekilde yürütmüşlerdir. Çocuklara 'Ç1, Ç2, Ç3...' kodları verilerek isimleri gizlenmiştir. Araştırmanın soru cümleleri doğrultusunda elde edilen verilerde içerik analizi yapılarak kodlar çıkarılmış ve kodlardan da temalara ulaşılmıştır. Ulaşılan kod ve temalar için bir akademisyenden görüş alınmıştır. Bu anlamda uzman incelemesi yoluyla geri bildirim ve yardım alınarak çalışmaya güvenilirlik katılmıştır (Creswell ve Miller, 2000). Ayrıca bulgular bölümünde kod ve temalar frekanslarla gösterilerek daha anlaşllır bir biçimde belirtilmeye çalışılmıştır. Görüşme formu ile elde edilen verilerin güvenirlik analizi için Miles ve Huberman'ın (1994) güvenirlik analizi formülünden yararlanılmıştır: Güvenirlik=Görüş birliği sayısı $\div$ (Görüş birliği+Görüş ayrllığı)x100 kullanılarak hesaplanabilir. İç tutarlıllı̆̆ gösteren bu değerin en az .80 olması gerekmektedir (Miles \& Huberman, 1994; Patton, 2002; Akt. Baltac1, 2017). Araştırmada \% 90 oranında görüş birliğine ulaşılmıştır. Buna göre görüşme verilerinin güvenilir olduğu kabul edilmektedir.

\section{BULGULAR}

Araştırmanın bu bölümünde okul öncesi dönem çocuklarının görüşme sırasında verdikleri cevaplar kod ve temalar biçiminde doğrudan alıntılarla desteklenerek tablolar halinde sunulmuştur.

Çocukların meslek kavramına yönelik görüşleri Tablo 1'de verilmiştir.

Tablo 1. Çocukların meslek kavramına yönelik görüssleri

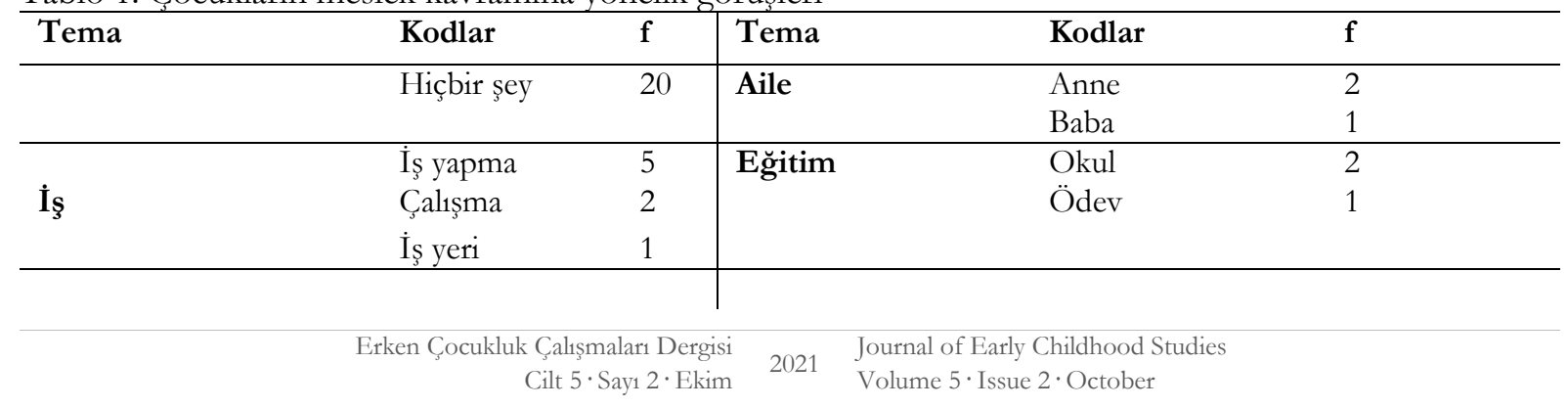




\begin{tabular}{|c|c|c|c|c|c|}
\hline \multirow{6}{*}{ Meslek Grupları } & \multirow{6}{*}{$\begin{array}{l}\text { Boyac1 } \\
\text { Koruyucu } \\
\text { Silah Satıcısı } \\
\text { Misırc1 } \\
\text { Ressam } \\
\text { Öğretmen } \\
\text { Baba }\end{array}$} & $\begin{array}{l}1 \\
1\end{array}$ & Oyun Oynamak & $\begin{array}{l}\text { Saklambaç } \\
\text { Yerden Yüksek }\end{array}$ & $\begin{array}{l}2 \\
1 \\
\end{array}$ \\
\hline & & 1 & & Dondurma & 1 \\
\hline & & 1 & & Mutluluk & 1 \\
\hline & & 1 & & Resim & 1 \\
\hline & & 1 & & & \\
\hline & & 1 & & & \\
\hline
\end{tabular}

Tablo 1 incelendiğinde çocukların yarıya yakını (20/42) meslek kavramına ilişkin akıllarına hiçbir şey gelmediğini belirtirlerken diğer çocukların bir bölümü (8/42) meslek kavramına ilişkin akıllarına işin, bir bölümü (7/42) meslek gruplarının geldiğini ifade etmişlerdir. Az sayıda çocuk ise aile (3/42), eğitim (3/42), oyun oynamak (3/42), dondurma, mutluluk ve resim (3/42) gibi kavramlar1 söylemişlerdir.

Çocukların bu konuyla ilgili görüşlerinden bazıları aşağıdaki gibidir.

C3: 'Hiçbir şey.'C7: 'Şey çalismak. 'Ç19: 'Okul geliyor.'C25: 'Saklambac geliyor.'Ç28: Kendi mesleğim aklima geliyor, ressamlik.'

Çocukların herkesin bir mesleğe sahip olmasına yönelik görüşleri Tablo 2'de sunulmuştur.

Tablo 2. Çocukların herkesin bir mesleğe sahip olmasına yönelik görüşleri

\begin{tabular}{|c|c|c|c|c|c|}
\hline Tema & Kodlar & $\mathrm{f}$ & Tema & Kodlar & $\mathrm{f}$ \\
\hline \multirow{11}{*}{ Mesleği Olmalı } & Bilmiyorum & 11 & \multirow{2}{*}{ Mesleği Olmamalı } & Bilmiyorum & 3 \\
\hline & Para Kazanma & 8 & & Tercih Etmeme & 2 \\
\hline & Okul & 4 & & Cevap Yok & 1 \\
\hline & İşin Olması Gerekir & 4 & & Bilmiyorum & 1 \\
\hline & Yiyecek Alma & 2 & & & \\
\hline & Yardım Etme & 1 & & & \\
\hline & Temizlik & 1 & & & \\
\hline & Düzenlilik & 1 & & & \\
\hline & Oyun Oynama & 1 & & & \\
\hline & Mutluluk & 1 & & & \\
\hline & İstedikleri Olur & 1 & & & \\
\hline
\end{tabular}

Tablo 2'de görüldüğü gibi çocukların tamamına yakını (35/42) herkesin bir mesleği olması gerektiğini belirtmişlerdir. Az sayıda çocuk ise (5/42) herkesin bir mesleğe sahip olmamas1 gerektiğini ifade etmiştir. Herkesin bir mesleği olmalı diyen çocukların bir kısmı (11/42) niçin olması gerektiğini bilmediklerini, bir kısmı ise (8/42) para kazanılması gerektiği için bir mesleği olması gerektiğini söylemişlerdir. Bazı çocuklar (4/42) okula gidilmesi ve işinin olması için bir mesleği olması gerektiğini dile getirirlerken, düşük sayıda bir grup çocuk ise (5/42) mesleği olmamalı derken bunun nedenini bilmediklerini $(3 / 42)$ ve meslekleri olmasinı tercih etmedikleri için (2/42) herkesin bir mesleği olmaması gerektiğini belirtmişlerdir.

Çocukların bu konuyla ilgili görüşlerinden bazıları aşağıdaki gibidir.

Ç:'Olmamal, bilmiyorum. 'Ç6: 'Evet, para kazanmak için çocuklara yiyecek almak için. 'Ç24: 'Olmali, çünkü olmazsa ne yapacağımı̨ bilmeyiz: 'C38: 'Olmamah, çünkü berkesin bilmesine gerek yok.'

Çocukların annelerinin mesleklerine yönelik görüşleri Tablo 3'de belirtilmiştir. 
Tablo 3. Çocukların annelerinin mesleklerinin olup olmayışına ilişskin görüşleri

\begin{tabular}{lll|lll}
\hline Tema & Kodlar & f & Tema & Kodlar & f \\
\hline \multirow{4}{*}{ Mesleği Var } & Ev İşleri & 12 & Mesleği Yok & Ev İşleri & 17 \\
\cline { 4 - 6 } & Öğretmen & 5 & & Bilmiyorum & 1 \\
& Bilmiyorum & 3 & & & \\
& İşçi & 2 & & & \\
& Aşçı & 1 & & & \\
& Hemşire & 1 & & & \\
\hline
\end{tabular}

Tablo 3'e göre çocukların yarısından fazlası (24/42) annelerinin bir mesleğe sahip olduğunu ifade etmişlerdir. Çocukların yarıya yakını ise (17/42) annelerinin bir mesleğe sahip olmadığını söylemişlerdir. Bir çocuk ise annesinin mesleğini bilmediğini dile getirmiştir. Annelerinin mesleği olduğunu söyleyen çocukların bir kısmı (12/42) annelerinin ev işi yaptığı için ev hanımlığını bir meslek olarak görmüşlerdir. Ancak annelerinin ev işleri yaptığını belirten diğer bir grup çocuk ise (17/42) annelerinin mesleği olmadığını belirtmişlerdir.

Çocukların bu konuyla ilgili görüşlerinden bazıları aşağıdaki gibidir.

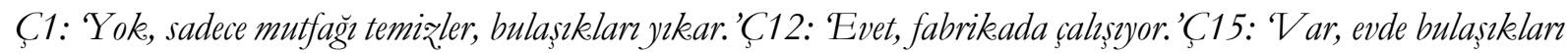
ynkar, evi siler.'Ç21: 'Evet, bilmiyorum. 'Ç36: 'V ar, ögretmen.'

Çocukların babalarının mesleklerine yönelik görüşleri Tablo 4'de verilmiştir.

Tablo 4. Cocukların babalarının mesleklerinin olup olmayışına ilișkin görüşleri

\begin{tabular}{lll|lll}
\hline Tema & Kodlar & f & Tema & Kodlar & f \\
\hline \multirow{4}{*}{ Mesleği Var } & Isş̧i & 11 & & Terzi & 1 \\
& Bilmiyorum & 9 & \multirow{3}{*}{ Mesleği Var } & Manav & 1 \\
& Öğretmen & 6 & Firnc1 & 1 \\
& Boyac1 & 3 & & Tatlıc1 & 1 \\
& Tamirci & 3 & & Bankacı & 1 \\
\cline { 2 - 5 } & Korucu & 2 & & Bilmiyorum & 1 \\
& Çiftçi & 2 & & & \\
\hline
\end{tabular}

Tablo 4'de görüldüğü üzere çocukların tamamına yakını (41/42) babalarının bir mesleğe sahip olduğunu belirtmişlerdir. Bir çocuk ise babasının mesleğini bilmediğini dile getirmiştir.

Çocukların bu konuyla ilgili görüşlerinden bazıları aşağıdaki gibidir.

Ç2: 'Var, boyacı.'Ç: 'Var, pamuklar toplar, biçer, tarlayn çapalar bu kadar. 'Ç14: 'Var, bilmiyorum. 'Ç29:

'Var, ögretmen.'C33: 'Var, seyde çalsıyor fabrikada. 'C34: 'Bilmiyorum.'

Çocukların büyüdüklerinde yapmak istedikleri mesleklere yönelik görüşleri Tablo 5'de sunulmuştur.

Tablo 5. Çocukların büyüdüklerinde yapmak istedikleri mesleklere yönelik görüşleri

\begin{tabular}{ll|ll}
\hline Kodlar & f & Kodlar & f \\
\hline Doktor & 10 & Hemşire & 2 \\
Öğretmen & 7 & Aşçı & 1 \\
Polis & 7 & Yarısçı & 1 \\
Asker & 2 & İtfaiyeci & 1 \\
Veteriner & 2 & Dermatolog & 1 \\
Ressam & 2 & Kuaför & 1 \\
Tamirci & 2 & Hiçbir Şey Olmak İstememekte & 1 \\
Pilot & 2 & & \\
\hline
\end{tabular}


Tablo 5 incelendiğinde çocukların tamamına yakını (41/42) büyüdüklerinde yapmak istedikleri meslekleri belirtmişlerdir. Bir çocuk ise büyüdüğünde hiçbir şey olmak istemediğini söylemiştir. Çocuklar en fazla doktor (10/42), öğretmen (7/42) ve polis (7/42) olmak istediklerini belirtmişlerdir.

Çocukların bu konuyla ilgili görüşlerinden bazıları aşağıdaki gibidir.

C4: 'Tamirci.'Ç: 'Doktor.'Ç10: Polis.'C20: 'Öğretmen.'Ç21: 'Hiçbir sey olmak istemiyorum.'C35: 'Ressam. 'C37: 'Hemsire. 'C42: 'Asker olmak.'

Çocukların büyüdüklerinde neden bu mesleği yapmayı istediklerine yönelik görüşleri Tablo 6'da belirtilmiştir.

Tablo 6. Çocukların büyüdüklerinde neden bu mesleği yapmayı istediklerine yönelik görüșleri

\begin{tabular}{|c|c|c|}
\hline Tema & Kodlar & f \\
\hline \multirow{6}{*}{ Doktor } & İyileştirmek için & 9 \\
\hline & İ̆ne Yapmak için & 3 \\
\hline & Büyümek için & 1 \\
\hline & Anne Olmak için & 1 \\
\hline & Annesine Hediye Almak için & 1 \\
\hline & Doktorluğu Sevdiği için & 1 \\
\hline \multirow{4}{*}{ Polis } & Suçluları Bulduğu için & 4 \\
\hline & Silahı Olduğu için & 2 \\
\hline & Hapse Attığ́ için & 1 \\
\hline & Polisliği Sevdiği için & 1 \\
\hline \multirow{4}{*}{ Öğretmen } & Öğretmeni Model Alma & 3 \\
\hline & Soru Sormak için & 1 \\
\hline & Çocuklara Yardım Etmek için & 1 \\
\hline & Rüyada Gördüğü için & 1 \\
\hline \multirow[t]{2}{*}{ Yarışç1/Tamirci } & Para Kazanmak için & 2 \\
\hline & Tamirciliği Sevdiği için & 1 \\
\hline \multirow[t]{2}{*}{ Asker } & Şehit Olmalarına Üzülme & 1 \\
\hline & Askerliği Sevdiği için & 1 \\
\hline \multirow{2}{*}{ Pilot } & Yolcular1 Bırakmay1 İsteme & 1 \\
\hline & Uçmay1 Sevdiği için & 1 \\
\hline Veteriner & Hayvanları Sevdiği için & 2 \\
\hline \multirow[t]{2}{*}{ Ressam } & Güzel Resim Yaptığı için & 1 \\
\hline & Resim Yapmayı Sevdiği için & 1 \\
\hline Kuaför & Saç Kesmeyi Sevdiği için & 1 \\
\hline Aşçı & Yemek Yapmayı Sevdiği için & 1 \\
\hline İtfaiyeci & İtfaiyeciliği Sevdiği için & 1 \\
\hline \multirow[t]{2}{*}{ Dermatolog } & Öyle Olmasını İstediği için & 1 \\
\hline & Hiçbir Şey Olmayı İstemiyor & 1 \\
\hline
\end{tabular}

Çocukların bir kısmı seçtikleri meslekleri sevdikleri için bu meslekleri yapmayı istediklerini dile getirirlerken, doktor olmayı isteyen çocuklar çoğunlukla hastaları iyileştirmeyi ve iğne yapmayı istedikleri için, polis olmayı isteyen çocuklar çoğunlukla suçluları bulmak ve polislerin silahları olduğu için, öğretmen olmak isteyen çocuklar ise çoğunlukla öğretmenlerini model aldıkları için bu mesleği yapmayı istediklerini söylemişlerdir.

Çocukların bu konuyla ilgili görüşlerinden bazıları aşağıdaki gibidir.

C5: İste, iğne yapmak istiyorum.'Ç10: 'Suçlular bulmak için hapse atmak için. 'Ç14: 'Cok seviyorum polis olmayı.'Ç20: ‘Cocuklara yardım etmek için. 'Ç25: ‘Cünkü ögretmenim gibi saygılı ve saygısız olmaya çalışzyorum 
o yüzden.'C29: 'Çünkü itfaiyecilïgi çok seviyorum.'C33: 'Cü̈nk̈̈ hayvanlar kontrol etmek istiyorum.'C38:

'Çünkü saçlar kesmek çok gürel oluyor.'

Çocukların öğretmen görseline ve öğretmenin yaptığı işlere yönelik görüşleri Tablo 7'de verilmiştir.

Tablo 7. Çocukların öğretmen görseline ve öğretmenin yaptı̆̆ işlere yönelik görüşleri

\begin{tabular}{|c|c|c|c|}
\hline Öğretmen & & Öğretmenin Yaptı̆̆ İşlere & \\
\hline Belirttikleri & & & \\
\hline Tema & $\mathrm{f}$ & Kodlar & f \\
\hline & & Ders Çalıștırır & 13 \\
\hline & & Ödev Verir & 8 \\
\hline & & Etkinlik Yaptırır & 3 \\
\hline & & Bilgi Verir & 3 \\
\hline & & Soru Sorar & 3 \\
\hline Öğretmen & 34 & Güçlendirir & 2 \\
\hline & & Sessiz Olun Der & 2 \\
\hline & & Gezdirir & 2 \\
\hline & & Resim Yaptrrır & 1 \\
\hline & & Meslek Sahibi Olmayı Sağlar & 1 \\
\hline & & Eğlendirir & 1 \\
\hline & & Bilmiyorum & 7 \\
\hline Bilmiyorum & 8 & Materyal Kullandirır & 1 \\
\hline
\end{tabular}

Tablo 7’ye göre çocukların çoğunluğu (34/42) öğretmen görseline öğretmen cevabını vermişlerdir. Az sayıda çocuk ise (8/42) öğretmen görseline bilmiyorum cevabını vermiştir. Öğretmen cevabını veren çocukların çoğunlukla öğretmenlerin ders çalıştırdığını, ödev verdiğini ve öğretici olduğunu söylemişlerdir. Öğretmen cevabını veren çocukların bir kısmı öğretmenlerin oyun oynattığını, etkinlik yaptırdı̆̆ını, bilgi verdiğini ve soru sorduğunu ifade etmişlerdir. Görsele bilmiyorum cevabını veren çocukların çoğunluğu görseldeki kişinin yaptığı işleri de bilmediğini belirtmiştir. Bilmiyorum cevabını veren çocuklardan birer çocuk ise görseldeki kişinin materyal kullandırdığını ve soru sorduğunu dile getirmiştir.

Çocukların bu konuyla ilgili görüşlerinden bazıları aşağıdaki gibidir.

Ç11: 'Öğretmen, ders çallştrrr çocuklar.'Ç19: 'Öğretmen, gel der boya yapturr.'Ç24: 'Öğretmen, çocuklarn çalısmasim, meslekleri, matematiği bilsin diye.'Ç29: 'Öğretmen, ögrretir.'Ç33: 'Bilmiyorum, çocuklara soru sorar.'Ç4: 'Ögretmen, bize oyun oynatır, etkinlikte yapar.'

Çocukların doktor görseline ve doktorun yaptı̆̆ işlere yönelik görüşleri Tablo 8'de sunulmuştur.

Tablo 8. Çocukların doktor görseline ve doktorun yaptı̆̆ işlere yönelik görüșleri

\begin{tabular}{llll}
\hline \multicolumn{2}{l}{ Doktor Görseline İlişkin Görüşler } & \multicolumn{2}{l}{ Doktorun Yaptı̆̆̀ İşlere İlişkin Görüşler } \\
\hline Belirttikleri Meslekler & f & Kodlar & f \\
\hline Tema & & İileştirir & 20 \\
& & Muayene Eder & 19 \\
\multirow{2}{*}{ Doktor } & \multirow{2}{*}{39} & Yardım Eder & 2 \\
& & Balon Verir & 1 \\
& & Iogne Vurur & 1 \\
\hline \multirow{2}{*}{ Bilmiyorum } & \multirow{2}{*}{3} & Bilmiyorum & 2 \\
& & İyileştirir & 1 \\
\hline
\end{tabular}


Tablo 8'de görüldüğü üzere çocukların tamamına yakını (39/42) doktor görseline doktor cevabını vermişlerdir. Az sayıda çocuk ise (3/42) doktor görseline bilmiyorum cevabını vermiştir. Doktor cevabını veren çocuklar çoğunlukla doktorların hastaları iyileştirdiğini ve muayene ettiğini belirtmişlerdir. Az sayıda çocuk ise serum taktıklarını, ilaç verdiklerini, yardımcı olduklarını, balon verdiklerini ve iğne vurduklarını ifade etmişlerdir. Görsele doktor cevabını veremeyen çocuklar görseldeki kişinin yaptığı işleri de bilmediğini belirtmiştir. Bilmiyorum cevabını veren bir çocuk ise görseldeki kişinin iyileştirdiğini söylemiştir.

Çocukların bu konuyla ilgili görüşlerinden bazıları aşağıdaki gibidir.

Ç1: 'Doktor, çocuklar hasta olduğunda bakar.'Ç13: Doktor, iğne vurur, serum takar.'Ç20: Bilmiyorum, çocuklar hasta etmez onlar.'C24: 'Doktor, ameliyat etmek, çok hasta olunca kusunca falan serum takarlar. 'Ç1:

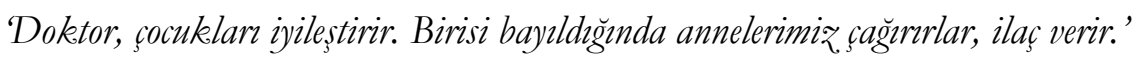

Çocukların asker görseline ve askerin yaptığı işlere yönelik görüşleri Tablo 9'da belirtilmiştir.

Tablo 9.Çocukların asker görseline ve askerin yaptığ ișlere yönelik görüsşeri

\begin{tabular}{llll}
\hline \multicolumn{2}{l}{ Asker Görseline İlişkin Görüşler } & \multicolumn{2}{l}{ Askerin Yaptı̆̆ı İşlere İlişkin Görüşler } \\
\hline Belirttikleri Meslekler & f & Kodlar & f \\
\hline Tema & & Düşmanı Öldürür & 17 \\
& & Savaşır & 10 \\
\multirow{2}{*}{ Asker } & 39 & Korur & 6 \\
& & Askere Gider & 1 \\
& & Hayvanları Vurur & 1 \\
\hline \multirow{2}{*}{ Bilmiyorum } & Bilmiyorum & 1 \\
\hline Polis & 2 & Bilmiyorum & 1 \\
\hline
\end{tabular}

Tablo 9 incelendiğinde çocukların tamamına yakını (39/42) asker görseline asker cevabını vermişlerdir. Az sayıda çocuk (2/42) asker görseline bilmiyorum, bir çocuk ise polis cevabını vermiştir. Asker cevabını veren çocuklar çoğunlukla askerin düşmanı öldürdüğünü, bir kısmı savaştığını belirtmişlerdir. Bazı çocuklar insanları koruduklarını, silah sıktıklarını, suçluları yakaladıklarını ifade etmişlerdir. Bir çocuk görsele asker cevabını vermiş ancak askerin yaptığı işi bilmediğini söylemiştir. Görsele bilmiyorum cevabını veren bir çocuk görseldeki kişinin yaptığı işleri bilmediğini belirtirken bir çocuk ise düşmanı öldürdüğünü ifade etmiştir. Bir çocuk ise görseldeki kişinin polis olduğunu ve suçluları yakaladığını dile getirmiştir.

Çocukların bu konuyla ilgili görüşlerinden bazıları aşağıdaki gibidir.

C8: 'Asker, biqi korur, hırsı‡lar yakalar. 'C15: 'Asker, savaşır.'C22: 'Asker, kötüleri öldürüyor.'C26: 'Polis, birsızlar yakalarlar. 'Ç41: 'Asker, silah sıkar.'

Çocukların polis görseline ve polisin yaptığı işlere yönelik görüşleri Tablo 10'da verilmiştir.

Tablo 10.Çocukların polis görseline ve polisin yaptığı işlere yönelik görüşleri

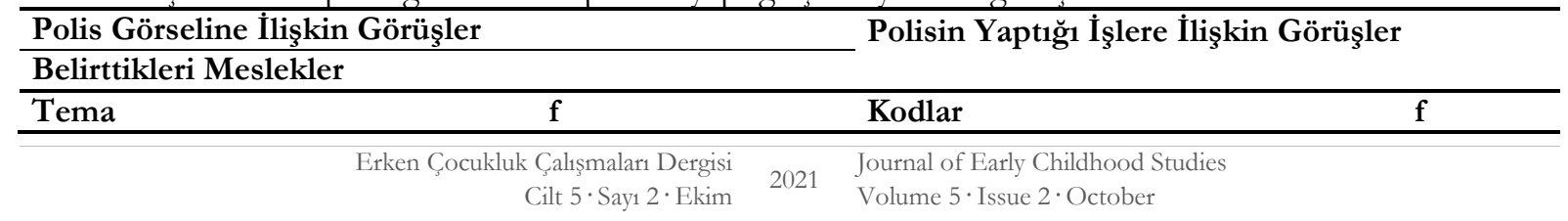




\begin{tabular}{|c|c|c|c|}
\hline \multirow{5}{*}{ Polis } & \multirow{5}{*}{41} & Suçluları Yakalar & 19 \\
\hline & & Hapse Atar & 15 \\
\hline & & Ceza Verir & 3 \\
\hline & & Hizlı Giderler & 2 \\
\hline & & Korur & 1 \\
\hline Bilmiyorum & 1 & Suçluları Yakalar & 1 \\
\hline
\end{tabular}

Tablo 10'da görüldüğ̈̈ gibi çocukların tamamına yakını (41/42) polis görseline polis cevabını vermişlerdir. Bir çocuk ise polis görseline bilmiyorum cevabını vermiştir. Polis cevabını veren çocuklar çoğunlukla polisin suçluları yakaladığını ve hapse attığını ifade etmişlerdir. Bazı çocuklar trafiğgi düzenlediklerini, düşmanı öldürdüklerini ve ceza verdiklerini belirtmiştir. Görsele bilmiyorum cevabını veren bir çocuk görseldeki kişinin suçluları yakaladığını söylemiştir.

Çocukların bu konuyla ilgili görüşlerinden bazıları aşağıdaki gibidir.

C9: 'Polis, hirsı̨lar hapse atar.' C22: 'Polis, insanlan korur.' C23: 'Polis, trafiği yapar, hirsı̨lar kovalar.' C36: 'Polis, trafik kurallarna uymayan birilerini hapse atar. Sonra da birileri kaçırldiğznda birsı̨̧lar yakalar.' Çocukların hemşire görseline ve hemşirenin yaptığı işlere yönelik görüşleri Tablo 11'de sunulmuştur.

Tablo 11.Cocukların hemșire görseline ve hemșirenin yaptığ işlere yönelik görüșleri

\begin{tabular}{|c|c|c|c|}
\hline \multirow{2}{*}{\multicolumn{2}{|c|}{$\begin{array}{l}\text { Hemşire Görseline İlişkin Görüşler } \\
\text { Belirttikleri Meslekler }\end{array}$}} & \multirow{2}{*}{\multicolumn{2}{|c|}{ Hemşirenin Yaptığı İşlere İlişkin Görüşler }} \\
\hline & & & \\
\hline Tema & f & Kodlar & $\mathrm{f}$ \\
\hline \multirow{6}{*}{ Doktor } & \multirow{6}{*}{18} & İğne Yapar & 7 \\
\hline & & Iyileştirir & 5 \\
\hline & & Tansiyon Ölçer & 1 \\
\hline & & Hastanede Çalışır & 1 \\
\hline & & Doğuma Yardım Eder & 1 \\
\hline & & Bilmiyorum & 1 \\
\hline \multirow{6}{*}{ Hemşire } & \multirow{6}{*}{13} & İğne Yapar & 7 \\
\hline & & Serum Takar & 5 \\
\hline & & Muayene Eder & 2 \\
\hline & & İyileştirir & 1 \\
\hline & & Ameliyata Girer & 1 \\
\hline & & Kan Alır & 1 \\
\hline \multirow{5}{*}{ Bilmiyorum } & \multirow{5}{*}{10} & Bilmiyorum & 4 \\
\hline & & İğne Yapar & 3 \\
\hline & & Muayene Eder & 1 \\
\hline & & Insanlara Yardım Eder & 1 \\
\hline & & Doğuma Yardım Eder & 1 \\
\hline Ameliyatç1 & 1 & İyileştirir & 1 \\
\hline
\end{tabular}

Tablo 11'e göre çocukların bir kısmı (18/42) hemşire görseline doktor, bir kısmı (13/42) hemşire, bir kısmı ise (10/42) bilmiyorum cevabını vermiştir. Bir çocuk ise hemşire görseline ameliyatçı cevabını vermiştir. Doktor cevabını veren çocuklar çoğunlukla görseldeki kişinin iğne yaptığını ve iyileştirdiğini belirtmişlerdir. Görseldeki kişiye hemşire cevabını veren çocuklar çoğunlukla hemşirenin iğne yaptığını ve serum taktığını ifade etmişlerdir. Ayrıca hemşirenin muayene ettiğini, iyileştirdiğini, ameliyata girdiğini ve kan aldığını söylemişlerdir. Görsele bilmiyorum cevabını veren 
çocukların bir kısmı görseldeki kişinin yaptığı işleri bilmediğini, bir kısmı iğne yaptığını, muayene ettiğini ve yardımcı olduğunu dile getirmiştir.

Çocukların bu konuyla ilgili görüşlerinden bazıları aşağıdaki gibidir.

Ç2: 'Doktor, iğne yapar.' C7: 'Doktor, hastalar iyilestirir, mesela çocuklar.' C14: 'Hemsire, koluna iğne yaparlar, bir de yardimcı olurlar serum takarlar.' C20: 'Bilmiyorum, çocuklara iğne vurmak.' C28: 'Hemşire, o da hasta olan kişileri iyileştirir.' C35: 'Hemsirire, ameliyata girer, kan alır.' C36: 'Hemşire, hastalar muayene eder, sonra serum takar.'

Çocukların itfaiyeci görseline ve itfaiyecinin yaptığı işlere yönelik görüşleri Tablo 12'de belirtilmiştir.

Tablo 12.Çocukların itfaiyeci görseline ve itfaiyecinin yaptığı işlere yönelik görüşleri

\begin{tabular}{|c|c|c|c|}
\hline \multicolumn{2}{|c|}{ İtfaiyeci Görseline İlişkin Görüşler } & \multicolumn{2}{|c|}{ İtfaiyecinin Yaptığ1 İşlere İlişkin Görüşler } \\
\hline \multicolumn{4}{|c|}{ Belirttikleri Meslekler } \\
\hline Tema & f & Kodlar & f \\
\hline İtfaiyeci & 33 & $\begin{array}{l}\text { Yang1n Söndürür } \\
\text { Hayvanları Kurtarır } \\
\text { İnsanlar1 Kurtarır }\end{array}$ & $\begin{array}{l}32 \\
3 \\
1\end{array}$ \\
\hline Yang1nc1 & 5 & Yang1n Söndürür & 5 \\
\hline Bilmiyorum & 4 & Yangin Söndürür & 4 \\
\hline
\end{tabular}

Tablo 12'de görüldüğü üzere çocukların çoğunluğu (33/42) itfaiyeci görseline itfaiyeci, az bir kısmı (5/42) yangıncı ve (4/42) bilmiyorum cevabını vermiştir. İtfaiyeci cevabını veren çocuklar çoğunlukla itfaiyecinin yangın söndürdügünü belirtmiştir. İtfaiyecinin hayvanları ve insanları kurtardığını ifade etmişlerdir. Görseldeki kişiye yangıncı cevabını veren çocuklar yangıncının yangını söndürdüğünü ifade etmişlerdir. Görsele bilmiyorum cevabını veren çocukların görseldeki kişinin yaptığı işin yangını söndürme olduğunu söylemişlerdir.

Çocukların bu konuyla ilgili görüşlerinden bazıları aşağıdaki gibidir.

C5: '̇tfaiyeci, yangznlar ıslatırlar.'C12: 'Bilmiyorum, yangınlar söndürür. 'Ç17: 'Ttfaiyeci, tabi ki yangın çıkarsa ona gider. 'C32: 'Yangıncı, bir şsyler yanarsa onlar söndürür. 'Ç35: 'Itfaiyeci, yangmlar söndürür, kedileri ağaçtan kurtarır. 'Ç39: İtfaiyeci, insanlarda yangın çıktı̆gnda itfaiyeci gelir ve onlar kurtarı ve içeri girer.'

Çocukların veteriner görseline ve veterinerin yaptı̆̆ işlere yönelik görüşleri Tablo 13'de verilmiştir.

Tablo 13.Çocukların veteriner görseline ve veterinerin yaptı̆̆ işlere yönelik görüşleri

\begin{tabular}{|c|c|c|c|}
\hline \multicolumn{2}{|c|}{ Veteriner Görseline İlişkin Görüşler } & \multicolumn{2}{|c|}{ Veterinerin Yaptığ1 İşlere İlişkin Görüşler } \\
\hline \multicolumn{2}{|c|}{ Belirttikleri Meslekler } & & \\
\hline Tema & $\mathbf{f}$ & Kodlar & $\mathbf{f}$ \\
\hline \multirow{2}{*}{ Doktor } & \multirow{2}{*}{14} & Hayvanlar1 Muayene Eder & 12 \\
\hline & & Hayvanları Iyileştirir & 5 \\
\hline \multirow{4}{*}{ Bilmiyorum } & \multirow{4}{*}{13} & Hayvanları Muayene Eder & 6 \\
\hline & & Hayvanları İyileştirir & 5 \\
\hline & & Hayvanları Besler & 1 \\
\hline & & Bilmiyorum & 1 \\
\hline \multirow{3}{*}{ Veteriner } & \multirow{3}{*}{8} & Hayvanları Iyileştirir & 5 \\
\hline & & Hayvanları Muayene Eder & 3 \\
\hline & & Hayvanlara İğne Yapar & 2 \\
\hline \multirow{2}{*}{ Hayvan Doktoru } & \multirow{2}{*}{4} & Hayvanlar1 Muayene Eder & 3 \\
\hline & & Hayvanları Iyileştirir & 1 \\
\hline
\end{tabular}




\begin{tabular}{|c|c|c|c|}
\hline Hemşire & 3 & $\begin{array}{l}\text { Hayvanları Iyileştirir } \\
\text { Hayvanları Muayene Eder }\end{array}$ & 2 \\
\hline
\end{tabular}

Tablo 13 incelendiğinde çocukların bir kısmı (14/42) veteriner görseline doktor, bir kısmı (13/42) bilmiyorum, bir kısmı ise (8/42) veteriner cevabını vermiştir. Çocukların bazıları (4/42) veteriner görseline hayvan doktoru ve (3/42) hemşire cevapları vermişlerdir. Doktor cevabını veren çocuklar görseldeki kişinin hayvanları muayene ettiğini ve iyileştirdiğini ifade etmişlerdir. Görsele bilmiyorum cevabını veren çocukların bir kısmı görseldeki kişinin hayvanları iyileştirdiğini, bir kısmı hayvanları muayene ettiğini, bir kısmı ise hayvanlara iğne yaptığını dile getirmiştir. Görsele bilmiyorum cevabını veren bir çocuk görseldeki kişinin yaptığı işleri bilmediğini söylemiştir. Görseldeki kişiye veteriner cevabını veren çocukların bir kısmı veterinerin hayvanları iyileştirdiğini, bir kısmı hayvanları muayene ettiğini, bir kısmı ise hayvanlara iğne yaptığını belirtmiştir. Görseldeki kişiye veteriner yerine hemşire cevabı veren çocuklar görseldeki kişinin hayvanları iyileştirdiğini ve muayene ettiğini söylemiştir. Görseldeki kişiye veteriner yerine hayvan doktoru cevabı veren çocuklar görseldeki kişinin hayvanları muayene ettiğini dile getirmiştir.

Çocukların bu konuyla ilgili görüşlerinden bazıları aşağıdaki gibidir.

C2: Doktor, kediyi iyileștirmek.' 'C6: 'Veteriner, hasta kediyi hasta köpekleri iyileștirir.'Ç17: 'Doktor, kedi yaralanırsa bakar, boğąına bakar iyileştirir. 'C28: 'Hemşire, hayvanlar tedavi eder. 'C34: 'Veteriner, hayvanlara yardim eder.'C41: 'Bilmiyorum, kedilere bakar tabi ki şey muayene eder.'

Çocukların çöpçü görseline ve çöpçünün yaptığ işlere yönelik görüşleri Tablo 14'de sunulmuştur.

Tablo 14.Cocukların çöpçü görseline ve çöpçünün yaptığ ișlere yönelik görüşleri

\begin{tabular}{llll}
\hline Çöpçü Görseline İlişkin Görüşler & & Çöpçünün Yaptığ İ ̧̇lere İlişkin Görrüşler \\
\hline Belirttikleri Meslekler & & Kodlar & f \\
\hline Tema & f & Çöpleri Temizler & 37 \\
\hline Çöpçü & 37 & Çöpleri Temizler & 4 \\
\hline \multirow{2}{*}{ Bilmiyorum } & 5 & Bilmiyorum & 1 \\
\hline
\end{tabular}

Tablo 14'de görüldüğü gibi çocukların çoğunluğu (37/42) çöpçü görseline çöpçü, bir kısmı ise (5/42) bilmiyorum cevabını vermiştir. Çöpçü cevabını veren çocukların tamamı çöpçünün çöpleri temizlediğini belirtmiştir. Görsele bilmiyorum cevabını veren çocukların çoğunluğu görseldeki kişinin çöpleri temizlediğini, bir çocuk ise görseldeki kişinin yaptı̆̆ işleri bilmediğini söylemiştir.

Çocukların bu konuyla ilgili görüşlerinden bazıları aşağıdaki gibidir.

C5: 'Bilmiyorum, çöpleri pislikleri süpürür, çöpe atar.'C13: 'Çöpçü, çöpleri süpürür.'C24: 'Çöpşü, çöpleri toplarlar

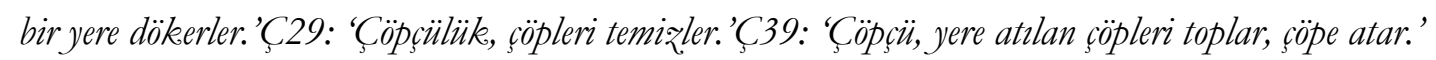

Çocukların şarkıcı görseline ve şarkıcının yaptığı işlere yönelik görüşleri Tablo 15'de belirtilmiştir. 
Tablo 15.Çocukların şarkıcı görseline ve şarkıcının yaptı̆̆ işlere yönelik görüşleri

\begin{tabular}{|c|c|c|c|}
\hline \multirow{2}{*}{\multicolumn{2}{|c|}{ SSarkıcı Görseline İlişkin Görüşler }} & \multirow{2}{*}{\multicolumn{2}{|c|}{ Şarkıcının Yaptı̆gı İşlere İlişkin Görüşler }} \\
\hline & & & \\
\hline Tema & $\mathrm{f}$ & Kodlar & $\mathrm{f}$ \\
\hline \multirow{2}{*}{ Şarkıc1 } & \multirow{2}{*}{16} & Şark1 Söyler & 10 \\
\hline & & Müzik Aleti Çalar & 8 \\
\hline \multirow{3}{*}{ Bilmiyorum } & \multirow{3}{*}{15} & Müzik Aleti Çalar & 12 \\
\hline & & Bilmiyorum & 2 \\
\hline & & Şarkı Söyler & 1 \\
\hline \multirow{2}{*}{ Müzikçi } & \multirow{2}{*}{9} & Müzik Aleti Çalar & 7 \\
\hline & & Şark1 Söyler & 2 \\
\hline Gitarc1 & 1 & Müzik Aleti Çalar & 1 \\
\hline Müzik & 1 & Müzik Aleti Çalar & 1 \\
\hline
\end{tabular}

Tablo 15'e göre çocukların bir kısmı (16/42) şarkıcı görseline şarkıc1, bir kısmı (15/42) bilmiyorum, bir kısmı ise (9/42) müzikçi cevabını vermiştir. Birer çocuk görseldeki kişiye şarkıcı yerine gitarcı ve müzik cevabını vermiştir. Şarkıcı cevabını veren çocuklar görseldeki kişinin şarkı söylediğini ve müzik aleti çaldığını dile getirmişlerdir. Görsele bilmiyorum cevabını veren çocukların bir kısmı görseldeki kişinin müzik aleti çaldığını, iki çocuk görseldeki kişinin yaptığı işleri bilmediğini, bir çocuk ise şarkı söylediğini ifade etmiştir. Görseldeki kişiye şarkıcı yerine müzikçi cevabı veren çocuklar çoğunlukla görseldeki kişinin müzik aleti çaldığını ve şarkı söylediğini söylemiştir. Görseldeki kişiye şarkıcı yerine gitarcı ve müzik cevabı veren çocuklar görseldeki kişinin müzik aleti çaldığını belirtmiştir.

Çocukların bu konuyla ilgili görüşlerinden bazıları aşağıdaki gibidir.

Ç1: 'Mürikeçi, eve giderler üstünü giyerler, güzel değilse sonra giyerler. Sonra müzik çaldnğ yere gider. Müzik çalar.'Ç7: Bilmiyorum, müz̨ik çalar.'Ç26: 'Şarkıcı, şarkı söyler.'C29: 'Şarkııı, gitar çalar bir şeyler çalar

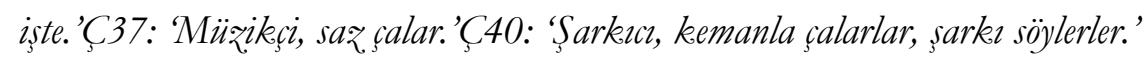

Çocukların kasap görseline ve kasabın yaptığı işlere yönelik görüşleri Tablo 16'da verilmiştir

Tablo 16. Çocukların kasap görseline ve kasabın yaptığı işlere yönelik görüşleri

\begin{tabular}{|c|c|c|c|}
\hline \multirow{2}{*}{\multicolumn{2}{|c|}{$\begin{array}{l}\text { Kasap Görseline İlişkin Görüşler } \\
\text { Belirttikleri Meslekler }\end{array}$}} & \multirow{2}{*}{\multicolumn{2}{|c|}{ Kasabın Yaptığ1 İşlere İlişkin Görüşler }} \\
\hline & & & \\
\hline Tema & $\mathrm{f}$ & Kodlar & $\mathrm{f}$ \\
\hline \multirow{4}{*}{ Bilmiyorum } & \multirow{4}{*}{22} & Et Keser & 18 \\
\hline & & Bilmiyorum & 4 \\
\hline & & Et Pişirir & 2 \\
\hline & & Et Satar & 1 \\
\hline Etçi & 9 & Et Keser & 9 \\
\hline \multirow{2}{*}{ Aşç1 } & \multirow{2}{*}{3} & Et Keser & 2 \\
\hline & & Et Satar & 1 \\
\hline Yemekçi & 3 & Yemek Yapar & 3 \\
\hline Kasap & 2 & Yemek Yapar & 2 \\
\hline Dönerci & 1 & Döner Yapar & 1 \\
\hline Kebapçı & 1 & Et Keser & 1 \\
\hline Yardımc1 & 1 & Et Keser & 1 \\
\hline
\end{tabular}

Tablo 16'da görüldüğü üzere çocukların yarısından fazlası (22/42) kasap görseline bilmiyorum cevabını vermiştir. Çocukların bir kısmı (9/42) kasap görseline etçi, az bir kısmı (3/42) yemekçi ve 
aşçı cevabını vermiştir. Bilmiyorum cevabını veren çocukların çoğunluğu görseldeki kişinin et kestiğini ifade etmişlerdir. Bilmiyorum diyen çocukların bazıları görseldeki kişinin yaptığı işleri bilmediğini söylemiştir. Görseldeki kişiye kasap yerine etçi cevabını veren çocukların tamamı görseldeki kişinin et kestiğini belirtmişlerdir. Görseldeki kişiye kasap cevabı veren çocuklar kasabın et kestiğini ve sattığını ifade etmişlerdir. Görseldeki kişiye kasap yerine yemekçi cevabı veren çocuklar görseldeki kişinin et kestiğini ve sattığını, aşçı cevabı veren çocuklar yemek yaptığını, kebapçı ve yardımcı cevabı veren çocuklar ise et kestiğini söylemiştir.

Çocukların bu konuyla ilgili görüşlerinden bazıları aşağıdaki gibidir.

Ç2: 'Bilmiyorum, etleri doğramak.Ç13: 'Etçi, et keser.'Ç18: 'Yemekçi, et kesmek.'Ç25: 'Etçi, etleri biri istediğinde iki iki ayurr. Possetlere ya da kaplara koyup verir.'C28: 'Kasap, etleri doğrar.'Ç31: Bilmiyorum, keçilerin etlerini keser eve götürür evde yeriz:'

Çocukların aşçı görseline ve aşçının yaptığı işlere yönelik görüşleri Tablo 17'de sunulmuştur.

Tablo 17. Cocukların aşçı görseline ve aşçının yaptı̆̆ ișlere yönelik görüssleri

\begin{tabular}{|c|c|c|c|}
\hline \multicolumn{2}{|c|}{ Aşçı Görseline İlişkin Görüşler } & \multicolumn{2}{|c|}{ Aşçının Yaptığı İşlere İlişkin Görüşler } \\
\hline \multicolumn{4}{|c|}{ Belirttikleri Meslekler } \\
\hline Tema & $\mathrm{f}$ & Kodlar & f \\
\hline \multirow{3}{*}{ Bilmiyorum } & \multirow{3}{*}{18} & Yemek Yapar & 13 \\
\hline & & Bilmiyorum & 4 \\
\hline & & Yemek Dağıtır & 3 \\
\hline \multirow{2}{*}{ Yemekçi } & \multirow{2}{*}{12} & Yemek Yapar & 11 \\
\hline & & Yemek Dağıtır & 3 \\
\hline \multirow{2}{*}{ Aşç1 } & \multirow{2}{*}{11} & Yemek Yapar & 10 \\
\hline & & Yemek Dağıtır & 3 \\
\hline Dondurmac1 & 1 & Dondurma Yapar & 1 \\
\hline
\end{tabular}

Tablo 17'ye göre çocukların yarıya yakını (18/42) aşçı görseline bilmiyorum cevabını vermiştir. Çocukların bir kısmı (12/42) aşçı görseline yemekçi, bir kısmı (11/42) aşçı cevabını vermiştir. Bir çocuk ise aşçı görseline dondurmacı cevabını vermiştir. Bilmiyorum cevabını veren çocukların çoğunluğu görseldeki kişinin yemek yaptığını belirtmişlerdir. Bilmiyorum diyen çocukların bazıları görseldeki kişinin yaptığı işleri bilmediğini bazıları ise yemek dağıtığını söylemiştir. Görseldeki kişiye aşçı yerine yemekçi cevabı veren çocuklar (12/42) çoğunlukla görseldeki kişinin yemek yaptığını, diğerleri ise yemek dağıttığını dile getirmiştir. Görseldeki kişiye aşçı cevabı veren çocukların çoğunluğu aşçının yemek yaptığını, diğerleri ise yemek dağıttığını belirtmişlerdir.

Çocukların bu konuyla ilgili görüşlerinden bazıları aşağıdaki gibidir.

Ç7: Bilmiyorum, yemek yapmak.'Ç16: Bilmiyorum.'C21: 'Yemekçi, yemek yapar.'C30: Kebapsı, etleri doğrar.'Ç39: 'Aş̧ı, insanlara yemek, götürür, yemek yapar.'

Çocukların makinist görseline ve makinistin yaptığı işlere yönelik görüşleri Tablo 18'de belirtilmiştir. 
Tablo 18. Çocukların makinist görseline ve makinistin yaptı̆̆ı işlere yönelik görüşleri

\begin{tabular}{|c|c|c|c|}
\hline \multicolumn{2}{|c|}{ Makinist Görseline İlişkin Görüşler } & \multirow{2}{*}{\multicolumn{2}{|c|}{ Makinistin Yaptığı İşlere İlişkin Görüşler }} \\
\hline \multicolumn{2}{|c|}{ Belirttikleri Meslekler } & & \\
\hline Tema & $\mathrm{f}$ & Kodlar & $\mathrm{f}$ \\
\hline \multirow{5}{*}{ Trenci } & \multirow{5}{*}{27} & Tren Sürer & 12 \\
\hline & & Yolcuyu İstediği Yere Bırakır & 11 \\
\hline & & Yolcuyu Gezdirir & 2 \\
\hline & & Yük Taşır & 2 \\
\hline & & Bilmiyorum & 2 \\
\hline \multirow{4}{*}{ Bilmiyorum } & \multirow{4}{*}{13} & Tren Sürer & 7 \\
\hline & & Bilmiyorum & 3 \\
\hline & & Yolcuyu İstediği Yere Bırakır & 2 \\
\hline & & Araba Sürer & 2 \\
\hline Dolmuşçu & 1 & Yolcuyu İstediği Yere Bırakır & 1 \\
\hline Uçakç1 & 1 & Sürer & 1 \\
\hline
\end{tabular}

Tablo 18'de görüldüğü gibi çocukların çoğunluğu (27/42) makinist görseline trenci, bir kısmı ise (13/42) bilmiyorum cevabını vermiştir. Birer çocuk ise makinist görseline dolmuşçu ve uçakçı cevabını vermiştir. Görseldeki kişiye makinist yerine trenci cevabı veren çocuklar çoğunlukla görseldeki kişinin tren sürdüğünü ve yolcuları istedikleri yere bıraktığını belirtmişlerdir. Bunun yanında yük taşıdıklarını, yolcuları gezdirdiklerini ve yaptıkları işi bilmediklerini ifade etmişlerdir. Bilmiyorum cevabını veren çocukların çoğunluğu görseldeki kişinin tren sürdüğünü söylemiştir.

Çocukların bu konuyla ilgili görüşlerinden bazıları aşağıdaki gibidir.

C3: 'Trenci, bilmiyorum.'C6: 'Trenci, tren sürer.'Ç13: 'Bilmiyorum.'C30: Bilmiyorum, tren sürmek. 'Ç42:

'Trenci, esyalar taşır.'

Çocukların pilot görseline ve pilotun yaptığı işlere yönelik görüşleri Tablo 19'da verilmiştir.

Tablo 19. Çocukların pilot görseline ve pilotun yaptığı işlere yönelik görüșleri

\begin{tabular}{|c|c|c|c|}
\hline \multirow{2}{*}{\multicolumn{2}{|c|}{$\begin{array}{l}\text { Pilot Görseline İlişkin Görüşler } \\
\text { Belirttikleri Meslekler }\end{array}$}} & \multirow{2}{*}{\multicolumn{2}{|c|}{ Pilotun Yaptığ1 İşlere İlişkin Görüşler }} \\
\hline & & & \\
\hline Tema & f & Kodlar & $\mathrm{f}$ \\
\hline \multirow{3}{*}{ Uçakçı } & \multirow{3}{*}{19} & Yolcuyu İstediği Yere Bırakır & 10 \\
\hline & & Uçak Sürer & 8 \\
\hline & & Bilmiyorum & 1 \\
\hline \multirow{3}{*}{ Bilmiyorum } & \multirow{3}{*}{14} & Uçak Sürer & 10 \\
\hline & & Bilmiyorum & 3 \\
\hline & & Yolcuyu İstediği Yere Bırakır & 1 \\
\hline \multirow{2}{*}{ Pilot } & \multirow{2}{*}{7} & Uçak Sürer & 6 \\
\hline & & Yolcuyu İstediği Yere Bırakır & 1 \\
\hline Uçak Şoförü & 1 & Yolcuyu İstediği Yere Bırakır & 1 \\
\hline Uçak Komiseri & 1 & Uçak Sürer & 1 \\
\hline
\end{tabular}

Tablo 19 incelendiğinde çocukların çoğunluğu (19/42) pilot görseline uçakçı, bir kısmı (14/42) bilmiyorum, bazı çocuklar ise (7/42) pilot cevabını vermiştir. Birer çocuk ise pilot görseline uçak şoförü ve uçak komiseri cevabını vermiştir. Görseldeki kişiye pilot yerine uçakçı cevabı veren çocuklar çoğunlukla görseldeki kişinin yolcuları istedikleri yere bıraktığını ve uçak sürdüğünü belirtmişlerdir. Bunun yanında yaptıklanı işi bilmediklerini ifade etmişlerdir. Bilmiyorum cevabını veren çocuklar çoğunlukla görseldeki kişinin uçak sürdügünü söylemişlerdir. Görsele bilmiyorum 
cevabını veren çocukların bir kısmı görseldeki kişinin yaptığı işleri de bilmediklerini dile getirmişlerdir. Görseldeki kişiye pilot cevabını veren çocuklar çoğunlukla pilotun uçak sürdüğünü ve bir çocuk ise yolcuları istedikleri yere bıraktığını ifade etmiştir.

Çocukların bu konuyla ilgili görüşlerinden bazıları aşağıdaki gibidir.

Ç1: 'Uçakeş, insanlarm gittiği yer varsa onları yaşadiğ yere bırakır. Ç14: 'Bilmiyorum, uçakla uçar. 'Ç18: Pilot, uçak sürmek. 'Ç23: 'Pilot, uşağ uçurur. 'Ç27: 'Uçakşı, uşak sürrer.'

Çocukların gemi kaptanı görseline ve gemi kaptanının yaptığı işlere yönelik görüşleri Tablo 20’de sunulmuştur.

Tablo 20. Çocukların gemi kaptanı görseline ve gemi kaptanının yaptığı işlere yönelik görüşleri

\begin{tabular}{|c|c|c|c|}
\hline \multicolumn{2}{|c|}{ Gemi Kaptanı Görseline İlişkin Görüşler } & \multicolumn{2}{|c|}{ Gemi Kaptanının Yaptığı İşlere İlişkin Görüşler } \\
\hline \multicolumn{4}{|c|}{ Belirttikleri Meslekler } \\
\hline Tema & $\mathrm{f}$ & Kodlar & $\mathrm{f}$ \\
\hline \multirow{4}{*}{ Gemici } & \multirow{4}{*}{23} & Yolcuyu İstediği Yere Bırakır & 12 \\
\hline & & Gemi Sürer & 11 \\
\hline & & Gemi Yüzdürür & 1 \\
\hline & & Balık Tutar & 1 \\
\hline \multirow{3}{*}{ Bilmiyorum } & \multirow{3}{*}{12} & Gemi Sürer & 8 \\
\hline & & Bilmiyorum & 3 \\
\hline & & Gemi Yüzdürür & 1 \\
\hline Gemi Kaptanı & 5 & Gemi Sürer & 5 \\
\hline Gemi Şoförü & 1 & Yolcuyu İstediği Yere Bırakır & 1 \\
\hline Korsan & 1 & Suda Gezer & 1 \\
\hline
\end{tabular}

Tablo 20'de görüldüğü üzere çocukların çoğunluğu (23/42) gemi kaptanı görseline gemici, bir kısmı (12/42) bilmiyorum, bazı çocuklar ise (5/42) gemi kaptanı cevabını vermiştir. Birer çocuk ise gemi kaptanı görseline gemi şoförü ve korsan cevabını vermiştir. Görseldeki kişiye gemi kaptanı yerine gemici cevabı veren çocuklar çoğunlukla görseldeki kişinin yolcuları istedikleri yere bıraktığını ve gemi sürdüğünü belirtmişlerdir. Bilmiyorum cevabını veren çocuklar çoğunlukla görseldeki kişinin gemi sürdüğünü söylemişlerdir. Görsele bilmiyorum cevabını veren çocukların bir kısmı görseldeki kişinin yaptığı işleri de bilmediklerini dile getirmişlerdir. Görseldeki kişiye gemi kaptanı cevabını veren çocukların tamamı gemi kaptanının gemi sürdüğünü ifade etmiştir.

Çocukların bu konuyla ilgili görüşlerinden bazıları aşağıdaki gibidir.

Ç1: 'Bilmiyorum, gemi sürmek. 'Ç4: 'Gemi kaptanı, gemi sürer. 'Ç10: 'Gemici, gemi sürer. 'Ç36: 'Gemici, sularda gemi sürer.'C41: 'Kaptan, gemiyi sürer.'

Çocukların kuaför görseline ve kuaförün yaptığı işlere yönelik görüşleri Tablo 21'de belirtilmiştir.

Tablo 21. Çocukların kuaför görseline ve kuaförün yaptığı ișlere yönelik görüş̧leri

\begin{tabular}{llll}
\hline Kuaför Görseline İlişkin Görüşler & & \multicolumn{2}{l}{ Kuaförün Yaptığı İşlere İlişkin Görüşler } \\
\hline Belirttikleri Meslekler & & Kodlar & f \\
\hline Tema & $\mathbf{f}$ & Saç Yapar & 23 \\
& & Saç Keser & 10 \\
Kuaför & \multirow{2}{*}{31} & Makyaj Yapar & 4 \\
& & Saç Boyar & 2 \\
& & Sakal Keser & 1 \\
\hline
\end{tabular}




\begin{tabular}{llll}
\hline Bilmiyorum & 8 & Saç Keser & 5 \\
& & Saç Yapar & 3 \\
& & Bilmiyorum & 1 \\
\hline Tiraşçı & 3 & Tiraş Yapar & 3 \\
\hline
\end{tabular}

Tablo 21'e göre çocukların çoğunluğu (31/42) kuaför görseline kuaför, bir k1smı (8/42) bilmiyorum, az bir kısmı ise (3/42) tıraşçı cevabını vermiştir. Kuaför cevabını veren çocuklar çoğunlukla kuaförün saç yaptığını ve saç kestiğini dile getirmişlerdir. Çocuklar kuaförün makyaj yaptığını, saç boyadığını ve sakal kestiğini de söylemişlerdir. Görsele bilmiyorum cevabını veren çocuklar çoğunlukla saç kestiğini ve saç yaptığını ifade etmişlerdir. Bunun yanında yaptığı işi bilmediğini söyleyen bir çocuk bulunmaktadır.

Çocukların bu konuyla ilgili görüşlerinden bazıları aşağıdaki gibidir.

Ç13: 'Kuaför, saç keser, duvak takar. 'Ç19: 'Bilmiyorum, saçın keser.' Ç29: 'Kuaför, saç keser ya da boyar. 'Ç35: 'Kuaför, şey kadınlarn saçlarm yapar, bu kadar.'C39: 'Kuaför, insanlarm saçın keser, çocuklarm da saçın keser.'

Çocukların terzi görseline ve terzinin yaptı̆̆ işlere yönelik görüşleri Tablo 22'de verilmiştir.

Tablo 22. Çocukların terzi görseline ve terzinin yaptığ ișlere yönelik görüșleri

\begin{tabular}{llll}
\hline \multicolumn{2}{l}{ Terzi Görseline İlişkin Görüşler } & \multicolumn{2}{l}{ Terzinin Yaptı̆̆ı İşlere İlişkin Görüşler } \\
\hline Belirttikleri Meslekler & f & Kodlar & f \\
\hline Tema & & Bilmiyorum & 13 \\
& 28 & Diker & 13 \\
Bilmiyorum & & Söker & 1 \\
& & Keser & 1 \\
\hline \multirow{2}{*}{ Dikmeci } & 8 & Diker & 8 \\
& & Bilmiyorum & 1 \\
\hline Terzi & 4 & Diker & 4 \\
\hline Örtücü & 1 & Örtü Satar & 1 \\
\hline Elbiseci & 1 & Elbise Yapar & 1 \\
\hline
\end{tabular}

Tablo 22'de görüldüğü gibi çocukların çoğunluğu (28/42) terzi görseline bilmiyorum, bir kısm1 (8/42) dikmeci, az bir kısmı ise (4/42) terzi cevabını vermiştir. Birer çocuk ise örtücü ve elbiseci cevabını vermiştir. Bilmiyorum cevabını veren çocuklar çoğunlukla terzinin yaptığı işi de bilmediğini dile getirmişlerdir. Bilmiyorum cevabını veren çocuklar çoğunlukla terzinin kıyafetleri diktiğini söylemişlerdir. Dikişçi cevabını veren çocuklar çoğunlukla kıyafetleri diktiğini belirtmişlerdir. Terzi cevabını veren çocukların tamamı terzinin kıyafet diktiğini ifade etmişlerdir. Çocukların bu konuyla ilgili görüşlerinden bazıları aşağıdaki gibidir.

Ç11: 'Bilmiyorum.' C24: 'Bilmiyorum, kıyafetleri diker.' C27: 'Dikiş̧̧i, şeyleri üstümüzdeki șeyleri götürürüz. diker.' C31: 'Terzi, elbiseleri diker etekleri, pijamalar, eșarplar.' C36: 'Terzi, bol gelen șeyleri keryafetteri biraz. düreltir.'

Çocukların garson görseline ve garsonun yaptığı işlere yönelik görüşleri Tablo 23'de sunulmuştur. 
Tablo 23. Çocukların garson görseline ve garsonun yaptığı işlere yönelik görüşleri

\begin{tabular}{|c|c|c|c|}
\hline \multirow{2}{*}{\multicolumn{2}{|c|}{$\begin{array}{l}\text { Garson Görseline İlişkin Görüşler } \\
\text { Belirttikleri Meslekler }\end{array}$}} & \multirow{2}{*}{\multicolumn{2}{|c|}{ Garsonun Yaptığı İşlere İlişkin Görüşler }} \\
\hline & & & \\
\hline Tema & $\mathrm{f}$ & Kodlar & $f$ \\
\hline \multirow{4}{*}{ Bilmiyorum } & \multirow{4}{*}{17} & Yemek Yapar & 10 \\
\hline & & Bilmiyorum & 4 \\
\hline & & Yemek Getirir & 3 \\
\hline & & Keser & 1 \\
\hline \multirow{3}{*}{ Yemekçi } & \multirow{3}{*}{12} & Yemek Yapar & 7 \\
\hline & & Yemek Getirir & 3 \\
\hline & & Yemek Satar & 1 \\
\hline \multirow{2}{*}{ Aşç1 } & \multirow{2}{*}{5} & Yemek Yapar & 4 \\
\hline & & Yemek Getirir & 2 \\
\hline Garson & 4 & Yemek Getirir & 4 \\
\hline \multirow[t]{2}{*}{ Kafeci } & 2 & Yemek Getirir & 1 \\
\hline & & Yemek Yapar & 1 \\
\hline Yardımc1 & 1 & Yemek Yapar & 1 \\
\hline Ziyafetçi & 1 & Yemek Yapar & 1 \\
\hline
\end{tabular}

Tablo 23 incelendiğinde çocukların yarıya yakını (17/42) garson görseline bilmiyorum, bir kısmı (12/42) yemekçi, az bir kısmı ise (5/42) aşçı ve garson (4/42) cevabını vermiştir. İki çocuk kafeci, birer çocuk ise yardımcı ve ziyafetçi cevabını vermiştir. Bilmiyorum cevabını veren çocuklar çoğunlukla görseldeki kişinin yemek yaptığını, bir kısmı ise yaptığı işi bilmediğini dile getirmişlerdir. Yemekçi cevabını veren çocuklar çoğunlukla görseldeki kişinin yemek yaptığını ve yemek getirdiğini belirtmişlerdir. Aşçı cevabını veren çocuklar görseldeki kişinin yemek yaptı̆̆ını ve yemek getirdiğini söylemişlerdir. Garson cevabını veren çocukların tamamı garsonun yemek getirdiğini ifade etmişlerdir. Çocukların bu konuyla ilgili görüşlerinden bazıları aşağıdaki gibidir.

Ç2: 'Bilmiyorum, yemek yapmak.' 'Ç10: 'Bilmiyorum, yemekleri getirir. 'Ç14: 'Aş̧ı, yemek götürür. 'Ç28: 'Garson, yemekleri acıktı̆̆mız̨a getirir. 'C32: 'Garson, yemek dağıtır.'

Çocukların inşaat işçisi görseline ve inşaat işçisinin yaptığ1 yönelik görüşleri Tablo 24'de belirtilmiştir.

Tablo 24. Çocukların inşaat iş̧̧isi görseline ve inşaat işçisinin yaptığ işlere yönelik görüşleri

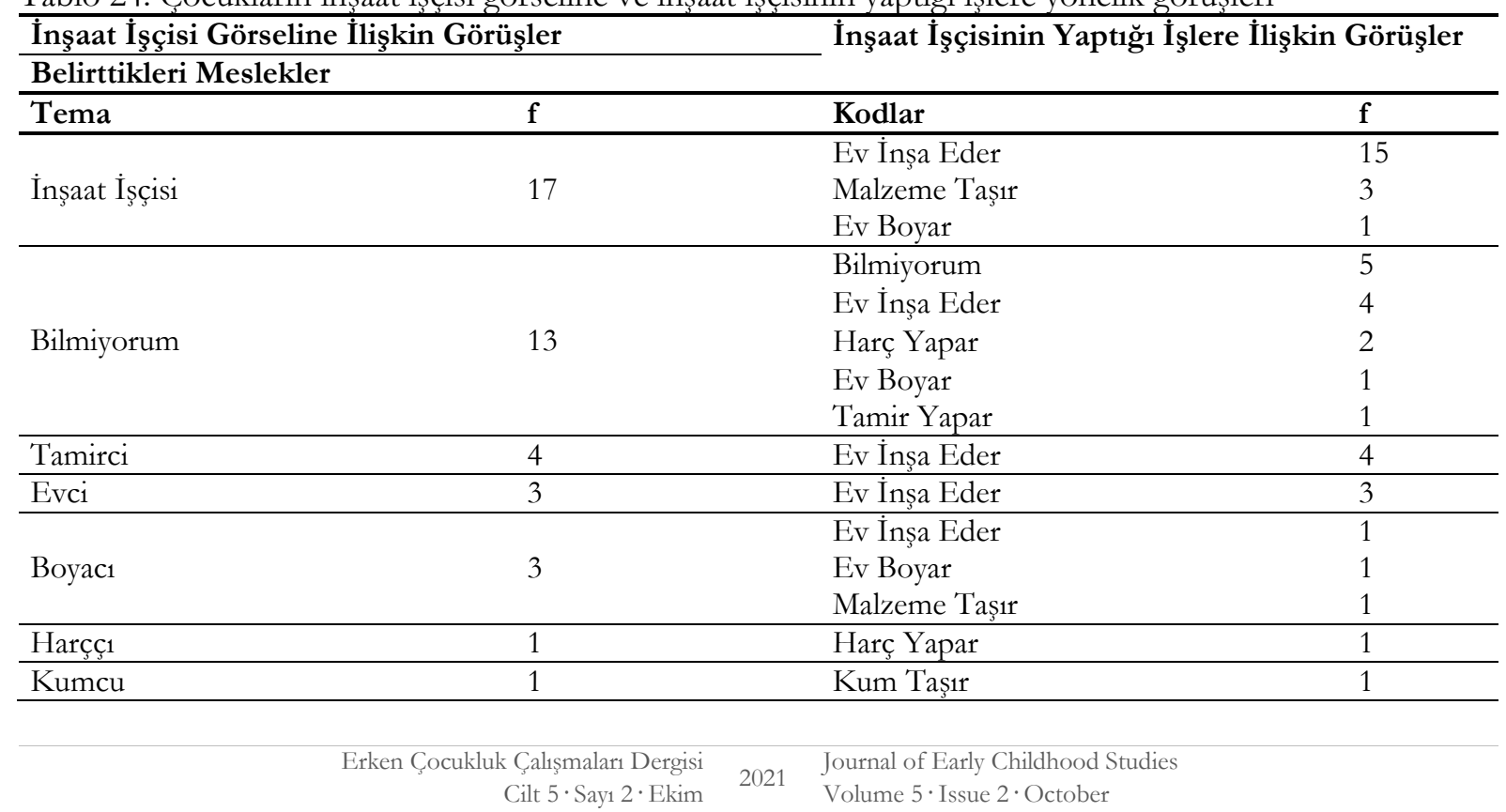


Tablo 24'de görüldüğü gibi çocukların yarıya yakını (17/42) inşaat işçisi görseline inşaat işçisi, bir kısmı (13/42) bilmiyorum, az bir kısmı ise (4/42) tamirci ve evci (3/42) cevabını vermiştir. Birer çocuk boyacı, harççı ve kumcu cevabını vermiştir. İnşaat işçisi cevabını veren çocuklar çoğunlukla inşaat işçisinin ev inşa ettiğini, az bir kısmı ise malzeme taşıdığını ve ev boyadığını söylemişlerdir. Bilmiyorum cevabını veren çocuklar çoğunlukla görseldeki kişinin yaptığı işi bilmediğini bir kısmı ise ev inşa ettiğini dile getirmişlerdir. Tamirci ve evci cevabını veren çocuklar görseldeki kişinin ev inşa ettiğini belirtmişlerdir.

Çocukların bu konuyla ilgili görüşlerinden bazıları aşağıdaki gibidir.

C1: İnşaatç, evleri inşaat etmek. ' C22: 'Tamirci, evi yapar.' C29: İnsaatçı, inşaat yapar.' C33: 'Evci, evi yapar,

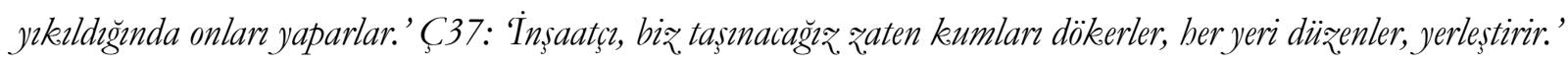
Çocukların tamirci görseline ve tamircinin yaptığı işlere yönelik görüşleri Tablo 25'de verilmiştir.

Tablo 25. Çocukların tamirci görseline ve tamircinin yaptığ ișlere yönelik görüșleri

\begin{tabular}{llll}
\hline \multicolumn{2}{l}{ Tamirci Görseline İlişkin Görüşler } & \multicolumn{2}{l}{ Tamircinin Yaptı̆̆ İşlere İlişkin Görüşler } \\
\hline Belirttikleri Meslekler & $\mathbf{f}$ & Kodlar & $\mathbf{f}$ \\
\hline Tema & 33 & Araba Tamir Eder & 20 \\
& & Eşya Tamir Eder & 11 \\
Tamirci & & Tamir Eder & 5 \\
& & Ev Tamir Eder & 1 \\
\hline \multirow{2}{*}{ Bilmiyorum } & \multirow{2}{*}{8} & Bilmiyorum & 4 \\
& & Araba Tamir Eder & 3 \\
\hline Silahç1 & Eşya Tamir Eder & 1 \\
\hline
\end{tabular}

Tablo 25’e göre çocukların çoğunluğu (33/42) tamirci görseline tamirci, bir kısmı (8/42) bilmiyorum cevabını vermiştir. Bir çocuk ise silahçı cevabını vermiştir. Tamirci cevabını veren çocuklar çoğunlukla tamircinin araba tamir ettiğini, bir kısmı eşya tamir ettiğini ve az bir kısmı ise sadece tamir ettiğini söylemişlerdir. Bilmiyorum cevabını veren çocuklar çoğunlukla görseldeki kişinin yaptığı işi bilmediğini bir kısmı ise araba tamir ettiğini dile getirmişlerdir. Silahçı cevabını veren bir çocuk ise silahçının silah yaptığını söylemiştir.

Çocukların bu konuyla ilgili görüşlerinden bazıları aşağıdaki gibidir.

C6: 'Tamirci, arabalan tamir eder, bozulmus bir şey varsa tablet, bilgisayar, televizyon ne varsa tamir eder. 'Ç11: 'Tamirci, arabalar tamir etmek. 'Ç19: 'Tamirci, kurnlmus bir șyleri yapar.'C25: 'Tamirci, bir șeyleri yapar ve bozulunca yeniden yapar.'

Çocukların imam görseline ve imamın yaptığı işlere yönelik görüşleri Tablo 26 'da sunulmuştur. 
Tablo 26. Çocukların imam görseline ve imamın yaptığı işlere yönelik görüşleri

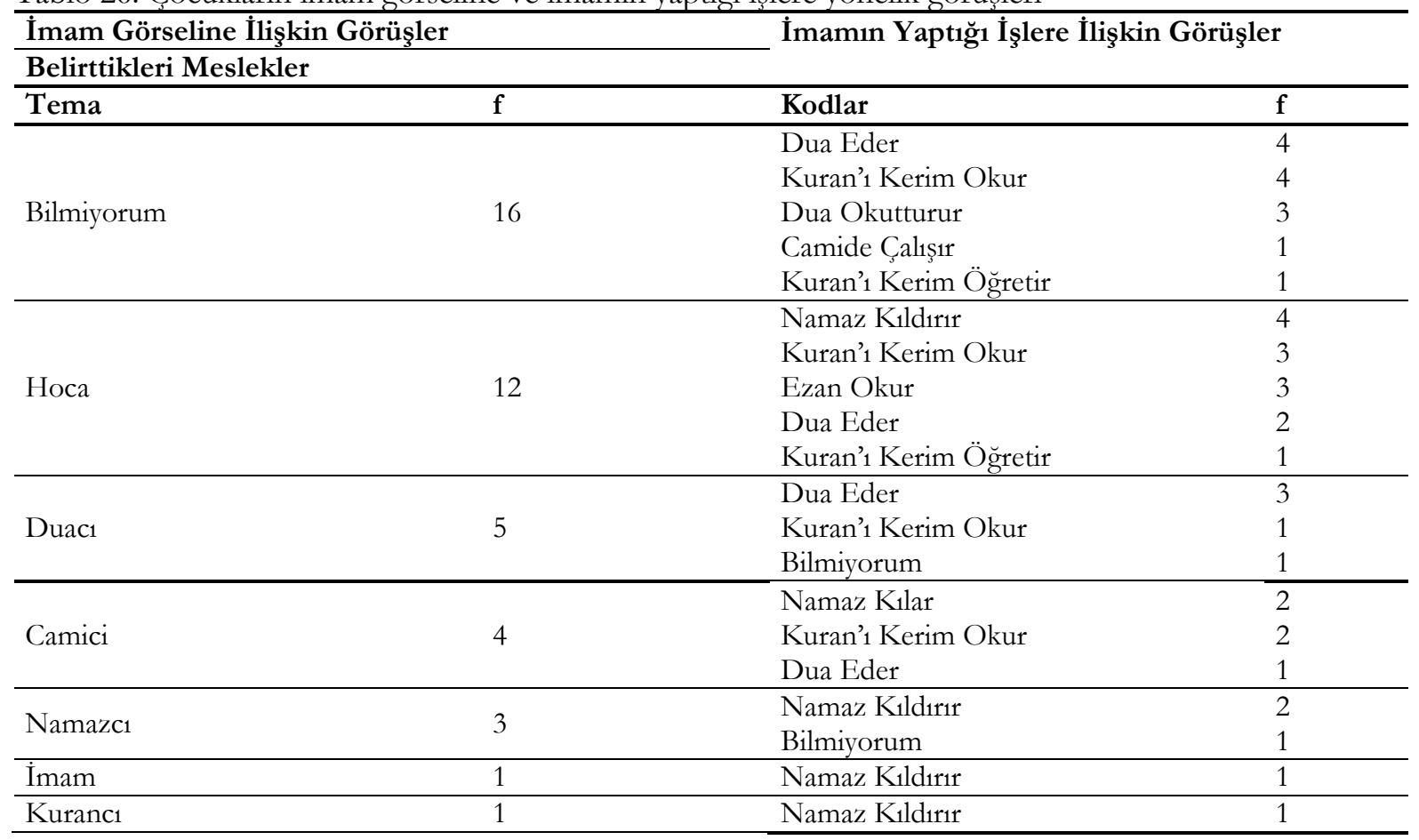

Tablo 26'da görüldüğü üzere çocukların yarıya yakını (16/42) imam görseline bilmiyorum, bir kısmı (12/42) hoca cevabını vermiştir. Çocukların az bir kısmı (5/42) duacı, (4/42) camici, (2/42) namazcı cevabını vermiştir. Bir çocuk ise imam ve Kurancı cevabını vermiştir. Bilmiyorum cevabını veren çocuklar çoğunlukla görseldeki kişinin yaptığı işi bilmediğini, dua ettiğini, Kuran’1 Kerim okuduğunu ve dua okutturduğunu söylemişlerdir. Hoca cevabını veren çocuklar hocanın çoğunlukla namaz kıldırdığını, Kuran’’ Kerim okuduğunu ve ezan okuduğunu belirtmişlerdir. İmam cevabını veren bir çocuk imamın namaz kıldırdığını ifade etmiştir.

Çocukların bu konuyla ilgili görüşlerinden bazıları aşağıdaki gibidir.

Ç5: 'Imam, namaz keldirrr. 'Ç9: 'Bilmiyorum, dua okumak. 'Ç32: 'Camici, bir şeyler okur. 'Ç38: 'Camici, dua okur, namaz kalar. 'C40: Hoca, Kuran okur.'

Çocukların futbolcu görseline ve futbolcunun yaptığ1 işlere yönelik görüşleri Tablo 27'de belirtilmiştir.

Tablo 27. Cocukların futbolcu görseline ve futbolcunun yaptığ işlere yönelik görüssleri

\begin{tabular}{llll}
\hline Futbolcu Görseline İlişkin Görüşler & \multicolumn{2}{l}{ Futbolcunun Yaptı̆̆ İşlere İlişkin Görüşler } \\
\hline Belirttikleri Meslekler & f & Kodlar & f \\
\hline Tema & 12 & Maç Yapar & 12 \\
\hline Maçç1 & 11 & Maç Yapar & 10 \\
\hline Bilmiyorum & Bilmiyorum & 1 \\
\hline Futbolcu & 9 & Maç Yapar & 8 \\
\hline Fopçu & Basket Atar & 1 \\
\hline Basketbolcu & 3 & Maç Yapar & 3 \\
\hline Golcü & 3 & Maç Yapar & 3 \\
\hline Gol & 2 & Gol Atar & 1 \\
\hline
\end{tabular}


Tablo 27 incelendiğinde çocukların bir kısmı (12/42) futbolcu görseline maççı, bir kısmı (11/42) bilmiyorum, bir kısmı ise (11/42) futbolcu cevabını vermiştir. Çocukların az bir kısmı (3/42) topçu, (3/42) futbol, (2/42) basketbolcu cevabını vermiştir. Birer çocuk ise golcü ve gol cevabını vermiştir. Maççı cevabını veren çocukların tamamı görseldeki kişinin maç yaptı̆̆ını söylemişlerdir. Bilmiyorum cevabını veren çocuklar çoğunlukla görseldeki kişinin maç yaptı̆̆ını, bir çocuk ise yaptı̆̆ işi bilmediğini belirtmiştir. Futbolcu cevabını veren çocuklar çoğunlukla futbolcunun maç yaptığını ifade etmişlerdir. Bir çocuk ise futbolcunu basket attığını söylemiştir. Topçu ve futbol cevabını veren çocukların tamamı görseldeki kişinin maç yaptığını dile getirmişlerdir. Basketbolcu cevabını veren çocuk görseldeki kişinin gol attığını, golcü cevabını veren çocuk maç yaptığını, gol cevabını veren çocuk ise gol attığını söylemiştir.

Çocukların bu konuyla ilgili görüşlerinden bazıları aşağıdaki gibidir.

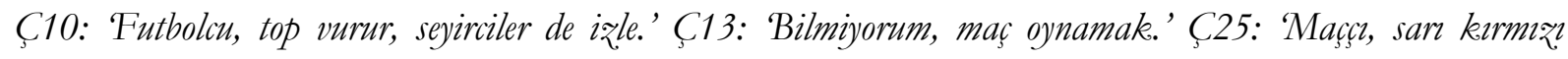
Galatasaray rengi yapar, maçlar ižleriz, babamla, gol atarlar.' C25: 'Maç̧, maç oynarlar.' C34: Futbolcu, kazanmak için kaleye gol atar.'

Çocukların şoför görseline ve şoförün yaptığı işlere yönelik görüşleri Tablo 28'de verilmiştir.

Tablo 28. Cocukların şoför görseline ve șoförün yaptığı işlere yönelik görüşleri

\begin{tabular}{|c|c|c|c|}
\hline \multirow{2}{*}{\multicolumn{2}{|c|}{$\begin{array}{l}\text { Şoför Görseline İlişkin Görüşler } \\
\text { Belirttikleri Meslekler }\end{array}$}} & \multicolumn{2}{|c|}{ Şoförün Yaptığ İşlere İlişkin Görüşler } \\
\hline & & & \\
\hline Tema & $\mathrm{f}$ & Kodlar & $\mathrm{f}$ \\
\hline \multirow{3}{*}{ Otobüsçü/Dolmuşçu } & \multirow{3}{*}{25} & Yolcuyu İstediği Yere Bırakır & 15 \\
\hline & & Araba Sürer & 11 \\
\hline & & Bilmiyorum & 2 \\
\hline \multirow{3}{*}{ Bilmiyorum } & \multirow{3}{*}{10} & Araba Sürer & 7 \\
\hline & & Bilmiyorum & 2 \\
\hline & & Yolcuyu İstediği Yere Bırakır & 1 \\
\hline \multirow[b]{2}{*}{ Şoför } & \multirow{2}{*}{5} & Yolcuyu İstediği Yere Bırakır & 3 \\
\hline & & Araba Sürer & 2 \\
\hline Arabac1 & 2 & Araba Sürer & 2 \\
\hline
\end{tabular}

Tablo 28'de görüldüğü gibi çocukların çoğunluğu (25/42) şoför görseline otobüsçü/dolmuşçu cevabını vermişlerdir. Çocukların bir kısmı (10/42) şoför görseline bilmiyorum, bazı çocuklar ise (5/42) şoför görseline şoför cevabını vermişlerdir. İki çocuk ise şoför görseline arabacı cevabını vermiştir. Otobüsçü/dolmuşçu cevabını veren çocuklar çoğunlukla görseldeki kişinin yolcuları istediği yere bıraktığını ve araba sürdügünü, iki çocuk ise yaptı̆̆ı işi bilmediğini belirtmiştir. Bilmiyorum cevabını veren çocuklar çoğunlukla görseldeki kişinin araba sürdüğünü söylemişlerdir. Bilmiyorum cevabını veren iki çocuk görseldeki kişinin yaptığı işi de bilmediğini, bir çocuk ise yolcuları istediği yere bıraktı̆̆ını ifade etmiştir. Şoför cevabını veren çocuklar şoförün yolcuları istediği yere bıraktığını ve araba sürdüğünü dile getirmişlerdir. Arabacı cevabını veren çocuklar ise görseldeki kişinin araba sürdüğünü söylemişlerdir.

Çocukların bu konuyla ilgili görüşlerinden bazıları aşağıdaki gibidir. 
C9: 'Dolmuşcu, herkesi bindirir, istediği yere götürür.' C10: 'Dolmuşcu, arabayı sürer, bayanlar ve adamlar gidecekleri yere götürür.' C17: 'Otobüsçü, otobüs sürer, çocuklarn götürür okul saati bittiüi için.' C24: 'Şoför, insanlar hemen istediği yere götürür.' C32: 'Otobüsçü, yolcular taşır, bir yere götürür.' C39: 'Otobüsçü, otobüs böyle gider giderken durağa brrakır.'

Çocukların astronot görseline ve astronotun yaptığı işlere yönelik görüşleri Tablo 29'da sunulmuştur.

Tablo 29. Çocukların astronot görseline ve astronotun yaptığı işlere yönelik görüşleri

\begin{tabular}{llll}
\hline \multicolumn{2}{l}{ Astronot Görseline İlişkin Görüşler } & Astronotun Yaptı̆̆ İşlere İlişkin Görüşler \\
\hline Belirttikleri Meslekler & $\mathbf{f}$ & Kodlar & f \\
\hline Tema & & Uzaya Gider & 8 \\
& \multirow{2}{*}{18} & Keşfeder & 4 \\
Uzayc1 & & Bilmiyorum & 4 \\
& & Rokete Biner & 1 \\
& & Özel Kiyafet Giyer & 1 \\
\hline & Bilmiyorum & 12 \\
Bilmiyorum & 17 & Uçar & 3 \\
& & Keşfeder & 1 \\
\hline \multirow{2}{*}{ Astronot } & Gezer & 5 \\
\hline Pilot & \multirow{2}{*}{5} & Uzaya Gider & 2 \\
\hline
\end{tabular}

Tablo 29'a göre çocukların yarıya yakını (18/42) astronot görseline uzaycı ve (17/42) bilmiyorum cevabını vermişlerdir. Çocukların bazıları (5/42) astronot görseline astronot cevabını vermişlerdir. İki çocuk ise astronot görseline pilot cevabını vermiştir. Uzaycı cevabını veren çocuklar çoğunlukla görseldeki kişinin uzaya gittiğini dile getirmişlerdir. Uzaycı cevabını veren çocukların bir kısmı görseldeki kişinin uzayda keşifte bulunduğunu, bir kısmı ise görseldeki kişinin ne iş yaptığını bilmediklerini ifade etmişlerdir. Bilmiyorum cevabını veren çocuklar çoğunlukla görseldeki kişinin ne iş yaptı̆̆ını bilmediklerini söylemişlerdir. Astronot cevabını veren çocuklar çoğunlukla astronotun uzaya gittiğini ve bunun yanı sıra Ay'da yürüdügünü dile getirmişlerdir. Pilot cevabını veren çocuklar ise görseldeki kişinin uzaya gittiğini söylemişlerdir.

Çocukların bu konuyla ilgili görüşlerinden bazıları aşağıdaki gibidir.

C6: 'Astronot, uqaya çıkar, u₹aydan bir şey bulup geri Dünya'ya gelirler.'C21: 'Bilmiyorum, u₹aya gitmek.' 'C25: 'Uzayca, bir seyleri inceler Dünya'ya getirir. 'Ç34: 'Uzaycı, bilmiyorum. 'Ç39: 'Bilmiyorum, uzayda uzun bakar, uzayda bir şey olmasm bekler.'

Çocukların eczacı görseline ve eczacının yaptığı işlere yönelik görüşleri Tablo 30'da belirtilmiştir.

Tablo 30. Çocukların eczacı görseline ve eczacının yaptı̆̆ işlere yönelik görüşleri

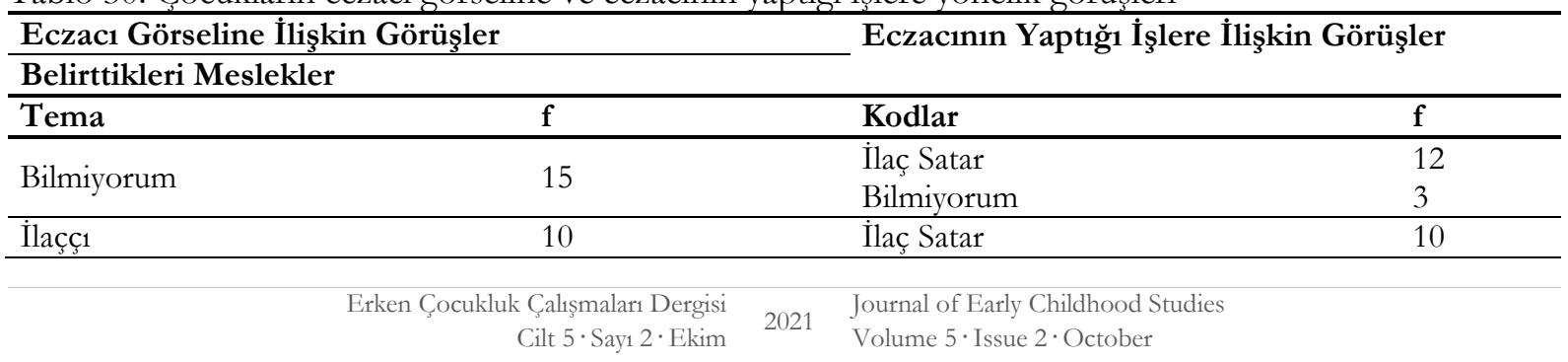




\begin{tabular}{llll}
\hline Eczac1 & 6 & İlaç Satar & 6 \\
\hline Doktor & 6 & İlaç Satar & 6 \\
\hline Şurupçu & 4 & İlaç Satar & 4 \\
\hline Hapç1 & 1 & İlaç Satar & 1 \\
\hline
\end{tabular}

Tablo 30'da görüldüğü üzere çocukların bir kısmı (15/42) eczacı görseline bilmiyorum ve (10/42) ilaççı cevabını vermişlerdir. Bazı çocuklar (6/42) eczacı görseline eczacı ve (6/42) doktor cevabını vermişlerdir. Dört çocuk eczacı görseline şurupçu, bir çocuk ise hapçı cevabını vermiştir. Bilmiyorum cevabını veren çocuklar çoğunlukla görseldeki kişinin ilaç sattığını dile getirmişlerdir. Bilmiyorum cevabını veren çocukların bazıları görseldeki kişinin yaptı̆̆ı işi de bilmediklerini söylemişlerdir. İlaççı, eczacı, doktor, şurupçu ve hapçı cevabını veren çocukların tamamı görseldeki kişinin ilaç sattığını ifade etmişlerdir.

Çocukların bu konuyla ilgili görüşlerinden bazıları aşağıdaki gibidir.

Ç10: Bilmiyorum, hasta olanlara şurup verir.'Ç14: Ṫlaçç, ilaç verir hastalara. 'Ç22: 'Doktor, hasta olanlara şurup ve hap verir. 'Ç27: 'Eçacı, hastalara ilaç verir. 'Ç31: 'Bilmiyorum, küçüklere ve büyüklere ilaç verir.' Ç40: 'Şurupsu, şuruplar verir hasta olduğumuzda.'

Çocukların bakkal görseline ve bakkalın yaptı̆̆ı işlere yönelik görüşleri Tablo 31'de verilmiştir.

Tablo 31. Çocukların bakkal görseline ve bakkalın yaptığı işlere yönelik görüşleri

\begin{tabular}{llll}
\hline \multicolumn{2}{l}{ Bakkal Görseline İlişkin Görüşler } & \multicolumn{2}{l}{ Bakkalın Yaptı̆̆ İşlere İlişkin Görüşler } \\
\hline Belirttikleri Meslekler & f & Kodlar & f \\
\hline Tema & 37 & Yiyecek Satar & 36 \\
Marketçi/Bakkal & 3 & Bilmiyorum & 1 \\
\hline Yiyecekçi & 1 & Yiyecek Satar & 3 \\
\hline Bilmiyorum & 1 & Bilmiyorum & 1 \\
\hline Satıc1 & Yiyecek Satar & 1 \\
\hline
\end{tabular}

Tablo 31 incelendiğinde çocukların tamamına yakını (37/42) bakkal görseline marketçi/bakkal cevabını vermişlerdir. Üç çocuk yiyecekçi, bir çocuk bilmiyorum ve bir çocuk satıcı cevabını vermiştir. Marketçi/bakkal cevabını veren çocukların tamamına yakını görseldeki kişinin yiyecek sattığını dile getirmişlerdir. Yiyecekçi cevabını veren çocukların tamamı görseldeki kişinin yiyecek sattığını ifade etmişlerdir. Bilmiyorum cevabını veren bir çocuk görseldeki kişinin yaptığı işi de bilmediğini söylemiştir. Satıcı cevabını veren bir çocuk görseldeki kişinin yiyecek sattığını belirtmiştir.

Çocukların bu konuyla ilgili görüşlerinden bazıları aşağıdaki gibidir.

Ç5: 'Marketçi, yiyecek verir.' Ç15: 'Yiyecekçi, yiyecek alurlar ondan sonra parasm verirler.' Ç17: Bakekal, bakkali açyor şeyleri satar, abur cuburlar satar.' Ç25: 'Marketçi, onlar bir şey satar mesela mu₹, elma.' C31: 'Bakkalcı, cips falan satar, çikolata satar.

Çocukların spiker görseline ve spikerin yaptığ işlere yönelik görüşleri Tablo 32'de sunulmuştur. 
Tablo 32.Çocukların spiker görseline ve spikerin yaptığı işlere yönelik görüşleri

\begin{tabular}{llll}
\multicolumn{2}{l}{ Spiker Görseline İlişkin Görüşler } & \multicolumn{2}{l}{ Spikerin Yaptığ İşlere İlişkin Görüşler } \\
\hline Belirttikleri Meslekler & & Kodlar & f \\
\hline Tema & f & Bilmiyorum & 15 \\
\hline Bilmiyorum & 24 & Haber Sunar & 9 \\
\hline Haberci & 17 & Haber Sunar & 15 \\
& & Bilmiyorum & 2 \\
\hline Reklamc1 & 1 & Reklam Üretir & 1 \\
\hline
\end{tabular}

Tablo 32'de görüldüğü gibi çocukların yarısından fazlası (24/42) spiker görseline bilmiyorum cevabını vermişlerdir. Çocukların yarıya yakını (17/42) spiker görseline haberci cevabını vermişlerdir. Bir çocuk ise spiker görseline reklamcı cevabını vermiştir. Bilmiyorum cevabını veren çocuklar çoğunlukla görseldeki kişinin ne iş yaptığını bilmediklerini dile getirmişlerdir. Bilmiyorum cevabını veren çocukların bir kısmı görseldeki kişinin haber sunduğunu ifade etmişlerdir. Haberci cevabını veren çocuklar çoğunlukla görseldeki kişinin haber sunduğunu, iki çocuk ise ne iş yaptı̆̆ını bilmediklerini belirtmişlerdir. Reklamcı cevabını veren bir çocuk ise görseldeki kişinin reklam ürettiğini söylemiştir.

Çocukların bu konuyla ilgili görüşlerinden bazıları aşağıdaki gibidir.

Ç6: 'Haberci, baberci seydir, televiayyonda bir şeyler olduğunda söyler kaydu almur.' Ç10: 'Bilmiyorum haberde olaylar olunca ne olduğunu anlatma.' C16: 'Bilmiyorum haberleri söyler.' C38: 'Haberci, insanlara televizyonda kötü haberleri gösterir.'

Buradan sonraki 5 meslek grubuna (hâkim, psikolog, mühendis, akademisyen ve YouTuber) ilişkin sorular çocuklara resim gösterilmeden yöneltilmiştir.

Çocukların hâkimin yaptığı işlere yönelik görüşleri Tablo 33'de belirtilmiştir.

Tablo 33.Çocukların hâkimin yaptığ ișlere yönelik görüșleri

\begin{tabular}{ll|ll}
\hline Yaptı̆̆ İşler & $\mathbf{f}$ & Yaptı̆̆ İşler & f \\
\hline Bilmiyorum & 35 & Yangı̈ Söndürür & 1 \\
\hline Davaya Bakar & 3 & Düdük Çalar & 1 \\
\hline İnsanları Korur & 2 & & \\
\hline
\end{tabular}

Tablo 33'e göre çocuklar çoğunlukla hâkimin ne iş yaptığını bilmediklerini dile getirmişlerdir. Üç çocuk hâkimin davaya baktığını, iki çocuk insanları koruduğunu, bir çocuk yangın söndürdüğünü, bir çocuk ise düdük çaldığını belirtmiştir.

Çocukların bu konuyla ilgili görüşlerinden bazıları aşağıdaki gibidir.

C10: 'Suçlulara hapse girmek ister misin diye sorar.'CC17:'Itfaiyeciler gibi yangm söndürebilir.'Ç25: 'Tabi ki de onlar da bâkim ya evli olanlar ayırr. 'Ç1: 'Bilmiyorum.'

Çocukların psikoloğun yaptığı işlere yönelik görüşleri Tablo 34'de verilmiştir.

Tablo 34.Çocukların psikoloğun yaptığ işlere yönelik görüşleri

\begin{tabular}{ll|ll}
\hline Yaptı̆̆1 İ̧̧ler & f & Yaptığı İşler & f \\
\hline Bilmiyorum & 30 & Yangına Bakar & 1 \\
\hline Hastayı İyileștirir & 3 & İğne Yapar & 1 \\
\hline
\end{tabular}




\begin{tabular}{ll|ll}
\hline Psikolojiyi İyileștirir & 1 & Yardım Eder & 1 \\
\hline Hızlı Koşar & 1 & İyi Davranır & 1 \\
\hline Tarihi Eser Bulur & 1 & Eğlendirir & 1 \\
\hline Film Çeker & 1 & & \\
\hline
\end{tabular}

Tablo 34'e göre çocuklar çoğunlukla psikoloğun ne iş yaptığını bilmediklerini dile getirmişlerdir. Üç çocuk psikoloğun hastayı iyileştirdiğini, birer çocuk ise psikolojiyi iyileştirdiğini, hızlı koştuğunu, tarihi eser bulduğunu, film çektiğini, yangına baktığını, iğne yaptı̆̆ını, yardım ettiğini, iyi davrandığını ve eğlendirdiğini dile getirmiştir.

Çocukların bu konuyla ilgili görüşlerinden bazıları aşağıdaki gibidir.

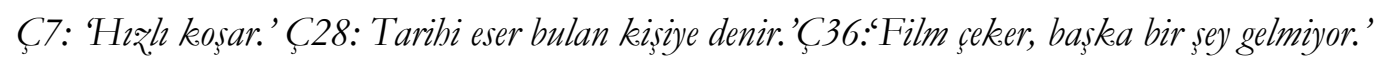

Çocukların mühendisin yaptığı işlere yönelik görüşleri Tablo 35'de verilmiştir.

Tablo 35.Çocukların mühendisin yaptı̆̆ işlere yönelik görüșleri

\begin{tabular}{ll|ll}
\hline Yaptı̆̆ı İ̧̧ler & f & Yaptı̆̆ İşler & f \\
\hline Bilmiyorum & 34 & İnşaat Yapar & 1 \\
\hline Yardım Eder & 2 & İcat Eder & 1 \\
\hline İnsanları Korur & 1 & Bakteri İnceler & 1 \\
\hline Tamir Yapar & 1 & İnternete Bakar & 1 \\
\hline
\end{tabular}

Tablo 35'de görüldüğü üzere çocuklar çoğunlukla mühendisin ne iş yaptığını bilmediklerini dile getirmişlerdir. Mühendisin insanlara yardımcı olduğunu ve koruduğunu, tamir ve inşaat yaptığını, icatlarda bulunduğunu, bakteri incelediğini, internete baktıklarını söylemişlerdir.

Çocukların bu konuyla ilgili görüşlerinden bazıları aşağıdaki gibidir.

C6: 'Bir seyi icat etmeyi başarrlar aklıma bu geldi.' C20: Kendisi, bize yardim eder.'C35: 'Şey, bakterileri göremediüi seyleri görür. 'C42: 'Bilmiyorum.'

Çocukların akademisyenin yaptığı işlere yönelik görüşleri Tablo 36'da sunulmuştur.

Tablo 36.Çocukların akademisyenin yaptı̆̆ işlere yönelik görüşleri

\begin{tabular}{ll|ll}
\hline Yaptığı İ̧̧ler & f & Yaptı̆̆ İ̧̇ler & f \\
\hline Bilmiyorum & 38 & İlaç Verir & 1 \\
\hline Tamir Yapar & 1 & Uçak Sürer & 1 \\
\hline Doktor & 1 & & \\
\hline
\end{tabular}

Tablo 36 incelendiğinde çocuklar çoğunlukla akademisyenin ne iş yaptığını bilmediklerini dile getirmişlerdir. Akademisyenin tamir yaptığını, doktor olduğunu, ilaç verdiğini ve uçak sürdüğünü ifade etmişlerdir.

Çocukların bu konuyla ilgili görüşlerinden bazıları aşağıdaki gibidir.

Ç18: 'Şey işini yapar, tamir işini.' C30: 'Doktor mu çocuklara iyi bakar.' 'C36: 'Onlar da ilaç verir.'Ç40: 'Uçak sürer.'

Çocukların YouTuberın yaptığı işlere yönelik görüşleri Tablo 37'de belirtilmiştir. 
Tablo 37.Çocukların YouTuberın yaptığı isslere yönelik görüşleri

\begin{tabular}{ll|ll}
\hline Yaptı̆̆ İ்̧ler & f & Yaptı̆̆ İşler & f \\
\hline Bilmiyorum & 21 & Takip Eder & 1 \\
\hline Youtube İzler & 9 & Savaşır & 1 \\
\hline Video Çeker & 8 & Kurtarır & 1 \\
\hline Bakkal & 1 & & \\
\hline
\end{tabular}

Tablo 37’de görüldüğü gibi çocuklar çoğunlukla YouTuberın ne iş yaptığını bilmediklerini belirtmişlerdir. YouTuberın YouTube izlediğini, video çektiklerini de söylemişlerdir.

Çocukların bu konuyla ilgili görüşlerinden bazıları aşağıdaki gibidir.

C9: 'Onlar ne is yapar, herkesi kurtarrlar.'C18: 'Şey işini yapar, bakkalcullk işini iște. 'Ç22: 'YouTuber, film izlettirir çocuklara, büyüklere annem yeni izliyor.'C35: 'Video çeker, abone olur, hayranlar olur, alttan şey geliyor altı.' C42: 'YouTuber mi YouTuber youtube yapar.'

\section{SONUÇ ve TARTIŞMA}

Bireyin mesleki tercihinin onun yaşam biçimini belirleyen önemli etkenlerden biri olduğunu söylemek mümkündür. İnsanlar meslek tercihlerinde karşılaştıkları seçenekleri değerlendirirken kendi kişilik yapılarının yanı sıra ilgi, gereksinim ve yeteneklerini göz ardı etmeden verecekleri kararlar daha gerçekçi olacaktır. Ancak bazı bireylerin bilgi ve deneyim eksikliğine bağlı olarak bunu tek başına yapabilmeleri her zaman mümkün olamadığından sağlanacak profesyonel yardım ve bilinçlendirici eğitim oldukça önemlidir. Meslek kavramının insan hayatındaki anlam ve önemine bağlı olarak, çocukluktan itibaren yapılacak rehberlik kapsamındaki yardım faaliyetlerinde, meslek tercihlerinde kişisel faktörlerin göz ardı edilmemesinin vurgulanmasının yanı sıra kendini gerçekleştirme kavramına da dikkat çekilerek bilinçlendirme çalışmalarının yapılması yarar sağlayıcı olacaktır. Bu anlamda anaokullarındaki öğrencilerle yapılan bu çalışma ile çocukların meslekleri ne ölçüde tanıdıkları, meslek kavramına ilişkin bilgi ve algı düzeyleri ile birlikte ileride tercih edecekleri mesleklere ilişkin düşünceleri belirlenmeye çalışılarak elde edilen bulgular tartışılmıştır.

Araştırma sonucuna göre çocukların yarıya yakınının meslek kavramına yönelik akıllarına hiçbir şey gelmediği, diğer çocukların ise meslek kavramına yönelik akıllarına iş, meslek grupları, aile, okul ve oyun oynamak geldiği tespit edilmiştir. Çocukların çoğunluğunun herkesin bir mesleği olması gerektiği düşüncesinde oldukları belirlenmiştir. Bu durum çocukların meslek kavramına ilişkin farkındalıkları açısından olumlu bir gelişmedir. Herkesin bir mesleği olmalı diyen çocukların insanların niçin meslek sahibi olmaları gerektiğini bilmedikleri bunun yanı sıra para kazanma, okula gitme ve insanların bir işinin olması gerektiği için meslek sahibi olmaları düşüncesinde oldukları görülmüştür. Aktın (2014) tarafindan yapılan bir araştırmada benzer sonuçlara ulaşılmış, okul öncesi dönemdeki çocukların anne babalarının para kazanmak, gereksinimlerini karşılamak için 
çalıştıklarını belirtmişlerdir. Benzer şekilde Karabekmez vd. (2018) araştırmalarında da okul öncesi dönemdeki çocukların meslek kavramını para kazanma, anne-babalarının işi, büyüdüklerinde olmak istedikleri meslekler olarak açıkladıkları görülmüsstür.

Araştırma sonucunda çocukların çoğunluğunun annelerinin bir mesleği olduğunu ve annelerinin yaptığı ev işlerini meslek olarak gördükleri belirlenmiştir. Ayrıca annelerinin bir mesleği olmadığını belirten çocukların annelerinin ev işi yaptıklarını söylemelerine rağmen ev işlerini bir meslek olarak görmedikleri sonucuna ulaşılmıştır. Yine çocukların tamamına yakınının babalarının bir mesleği olduğunu ve onların işçi, öğretmen, boyacı ve tamirci olarak çalıştıklarını bildikleri görülmüştür. Bunun yanı sıra babalarının mesleği olduğunu belirten çocukların bir kısmı babalarının mesleğinin ne olduğunu bilememişlerdir. Alanyazın incelendiğinde Lee (2012) anaokuluna devam eden 5-6 yaş çocukları ile yaptığı araştırmada çocukların çoğunluğunun ebeveynlerinin mesleklerini tanıdıkları sonucuna ulaşmıştır. Bu anlamda çocukların anne ve babalarının mesleklerine yönelik bilgilerinin olduğu söylenebilir. Ancak çocukların annelerinin yaptığı ev işlerini mesleği olması açısından farklı yorumladıkları görülmektedir. Çocukların yaşadığı bu ikileme meslek gruplarını, yaptığ işlerle ilişkilendirmeleri neden olmuş olabilir. Bu durum çocukların annelerinin ev işi yapmalarını meslek olarak nitelendirmelerini sağlamış olabilir.

Araştırmanın bir diğer sonucunda çocukların büyüdüklerinde en çok doktor, öğretmen ve polis olmak istedikleri tespit edilmiştir. Alanyazın incelendiğinde Trice ve King (1991) tarafindan yürütülen araştırmada anaokuluna devam eden erkek çocukların polis, pilot ve doktor, kız çocukların ise hemşire, öğretmen ve doktor olmak istedikleri ortaya çıkmıştır. Lee (2012) yaptığ1 araştırmada çocukların en çok yapmak istedikleri mesleklerin öğretmenlik, polislik ve doktorluk olduğunu tespit etmiştir. Genç ve Alkan Ersoy (2016) tarafından yapılan araştırmada da çocukların büyüdüklerinde daha çok doktor ve polis olmak istedikleri sonucuna ulaşılmıştır. Günşen vd. (2019) araştırmasında 5 yaş çocuklarının büyüyünce doktor ve öğretmen olmayı tercih ettikleri görülmüştür. Temiz vd. (2020) tarafindan yürütülen araştırmada çocukların en çok öğretmen, doktor, asker ve polis olmak istedikleri belirlenmiştir. Bu araştırmanın sonuçları elde ettiğimiz sonuçları destekler niteliktedir. Yine Aktın'ın (2014) çocuklarla ilgili çalışmasında da çocukların büyüdüklerinde hemşire, itfaiyeci, otobüs şoförü, doktor, astronot, jimnastikçi ve anne olmak istedikleri ortaya çıkmıstır. Bu duruma bağlı olarak sonuçlar arasında bir benzerlik olduğu söylenebilir. Çocukların çoğunlukla iyileştirmek ve iğne yapmak için doktor olmak istedikleri, öğretmenlerini model aldıkları için öğretmen olmak istedikleri, suçluları bulduğu ve silahları olduğu için polis olmak istedikleri belirlenmiştir. Bunun yanı sıra çocukların meslek tercihlerinde; mesleklerin işlevleri, kişisel değerler, para kazanma ve sevgi faktörlerinin etkili olduğu görülmektedir. Benzer sonuçlara Genç ve Alkan Ersoy'un (2016) ve Temiz vd. (2020) 
araştırmalarında da ulaşılmış, ilgili araştırmada çocukların meslek seçiminde sevginin ve kişisel değerlerin etkisi olduğu belirlenmiştir. Araştırma sonuçlan benzer niteliktedir. Çocukların çoğunlukla doktor, öğretmen ve polis mesleklerini tercih etmelerine toplumsal değerlerin, yargıların, düşüncelerin ve yönlendirmelerin etkisi olduğu düşünülebilir. Ayrıca çocukların yaşamlarının ilk yıllarında bu meslek gruplarıyla daha çok karşılaşmaları meslek tercihlerini etkilemiş olabilir. Bunun yanı sıra çocukların geleceğin meslekleriyle ilgili bilgi sahibi olmaları ilerleyen yaşamlarında meslek seçimlerini etkileyeceği düşünülebilir. Sonuç olarak okul öncesi dönemdeki çocukların büyüdüklerinde bir meslek sahibi olmayı istedikleri ve neden bu mesleği yapmak istediklerine yönelik düşünceler geliştirdikleri görülmüştür.

Araştırmada elde edilen bulgulara göre çocukların çoğunluğunun öğretmen, doktor, asker ve polis görsellerine bağlı olarak bu gruptaki meslekleri tanıdıkları ve isimlendirdikleri, yaptığı işler hakkında bilgilerinin olduğu söylenebilir. Bu durum çocukların bu meslek gruplarıly olan etkileşimlerinin daha fazla olmasindan, bu meslek gruplarının medyada sıklıkla yer almasindan ve toplumda kendine daha çok yer bulmasından kaynaklanmış olabilir. Diğer yandan çocukların çoğunluğunun hemşire görseline doktor cevabını vermelerine rağmen hemşirenin yaptığı işleri de bildikleri sonucuna ulaşılmıştır. Görsele doktor, bilmiyorum ve ameliyatçı cevabını verenler olmakla birlikte görseldeki kişinin yaptığı işler konusunda fikir sahibi oldukları düşünülmektedir. Yılmaz ve Işı1k Esenay (2020) yaptıkları araştırmada ilkokul öğrencileri hemşireleri iğne yapan, tedavi eden, doktora yardım eden, hastalara ve çocuklara bakan, hastaları iyileştiren bir meslek sahibi olarak belirtmişlerdir. $\mathrm{Bu}$ bağlamda okul öncesi çocukların ve ilkokul öğrencilerinin verdikleri cevaplarda paralellik olduğu görülmektedir. Bu durumda okul öncesi çocukların hastanede çalışan kişileri doktor ve hemşire olarak sınıflandırdıkları ancak aralarındaki farkı algılamakta zorlandıkları söylenebilir.

Araştırma sonucuna göre çocukların çoğunluğunun itfaiyeciyi tanıdığı görülmüştür. Bunun yanı sıra az bir kısmı yangıncı ve bilmiyorum cevapları vermekle birlikte çocukların görseldeki kişinin yaptı̆̆1 işi yangın söndürme olarak niteledikleri sonucuna ulaşılmıştır. Bu durumda çocukların itfaiyeci mesleğini tanıdıkları ve isimlendirdikleri, itfaiyecinin yaptığı işler hakkında bilgi sahibi oldukları söylenebilir. Ancak çocukların ve veterinerlik mesleğini pek fazla tanıyamadıklarını söylemek mümkündür. Veteriner görseline çoğunlukla doktor ve bilmiyorum cevabını vermişler, bir kısmı veterinerin yaptığı işleri hayvanları iyileştirme ve muayene etme, hayvanlara iğne yapma şeklinde belirtmiş olmakla birlikte genel olarak çocukların veterinerlik mesleğini isimlendirmekte ve tanımakta zorlandıkları ancak yaptığı işler konusunda bir düşünceye sahip oldukları görülmüştür.

Araştırmanın bir diğer sonucunda çöpçü görseline bilmiyorum cevabını veren çocuklar olmakla birlikte çocukların çoğunlukla çöpçü cevabını verdikleri belirlenmiş ve çöpçünün yaptığı işi çöpleri 
temizleme olarak açıklamışlardır. Bilmiyorum cevabını veren çocukların da görseldeki kişinin çöpleri temizlediğini söylemeleri çocukların çöpçü mesleğine ve çöpçünün yaptı̆̆1 işlere yönelik bir algıları olduğu ve bu mesleği tanıdıkları düşünülmektedir.

Araştırmada elde edilen diğer bir bulguya göre şarkıcı görseline şarkıcı cevabını veren çocuklar, şarkıcının yaptığı işleri şarkı söyleme ve müzik aleti çalma olarak belirtmişlerdir. Bilmiyorum, müzikçi, gitarcı ve müzik cevabını veren çocukların ise görseldeki kişinin müzik aleti çaldığı ve şarkı söylediği düşüncesinde oldukları görülmüştür. Bu durum çocukların şarkıcı mesleğini tanımada ve isimlendirmede zorlansalar da şarkıcının yaptığı işler konusunda fikir sahibi olduklarını düşündürmektedir.

Kasaplık mesleğine ilişkin olarak çocukların çok azının kasaplık mesleğini ismen bildiği, ancak büyük çoğunluğun kasaplığın ismini bilmese de yaptı̆̆ işler konusunda bilgiye sahip oldukları görülmektedir. Bu duruma kasapların artık müstakil kasap olarak işyeri çalıştırmaktan ziyade marketler kapsamındaki reyonlarda çalışıyor olmalarının etkisinin olduğu söylenebilir. Benzer şekilde çocukların büyük çoğunluğunun aşçı mesleğinin de ismini bilmediği ancak yaptıkları işleri bildikleri görülmektedir. İşlerini biliyor oluşlarındaki temel etkenin resmin görselliğinden ürettikleri düşünceler olmuş olabilir.

Makinistlik meslek ismini çocukların bilmediği ancak makinistlerin yaptıkları işlere ilişkin bilgiye sahip oldukları görülmektedir. Benzer şekilde pilotluk mesleğine ilişkin de çocuklar büyük oranda pilotların yaptıkları işi belirtmişler, çocukların ancak birkaçı pilotluğu ismen söylemişlerdir. Gemi kaptanlığında da benzer bulgulara ulaşılmış, birkaç çocuk dışında gemi kaptanlığının ismini söyleyememişler, ancak yaptıkları işleri belirtmişlerdir. Çocukların büyük çoğunluğunun bu mesleklerin isimlerine ilişkin bilgi eksikliklerinin içinde bulundukları çevrede günlük yaşantılarında tren, gemi ve uçağa ilişkin deneyimlerinin pek olmayışı, yine bu meslek gruplarındaki kişilerin sayısının azlığı ve kendi çevrelerindeki günlük konuşmalarda pek bahsedilmeyen meslekler oluşu neden olmuş olabilir.

Diğer yandan çocukların kuaför görseline çoğunlukla kuaför cevabını verdikleri görülmektedir. Bu durum çocukların kuaför mesleğini tanıdıklarını ve isimlendirdiklerini aynıca yaptığı işler konusunda fikir sahibi olduklarını düşündürtmektedir. Terzilik mesleğine ilişkin bulgular değerlendirildiğinde ise çocuklar terzilerin yaptıkları işleri söylemekle birlikte, büyük çoğunluğu terzilik görseline bağlı olarak yaptı̆̆ işi bilmiyorum demişlerdir. Bu durum hazır giyimin terzilik mesleğine olan gereksinimi azalttığı, bağlı olarak yaygın olmayan bir mesleğin çocuklar tarafindan tanınmadığını düşündürmektedir. Benzer şekilde çocukların garsonluk mesleğini de çok tanımadıkları görülmektedir. Ancak birkaç çocuk isimlendirebilmiş diğerleri yaptıkları işleri söylemişlerdir. $\mathrm{Bu}$ 
durum çocukların yakınlarıyla birlikte dışarıda garson bulunan ortamlarda çok bulunmadıklarını ve günlük yaşantılarında çevrelerinde bu mesleğe ilişkin duyumlarının az olduğunu düşündürtmektedir. Ancak çocukların inşaat işçiliği görseli tanıma oranlarının daha yüksek olduğu, yarısına yakını ismen bilmelerinin yanı sıra büyük çoğunluğu işçilerin yaptıkları işler konusunda da bilgiye sahip oldukları görülmektedir. Benzer şekilde toplumsal yaşamda daha yaygın bir şekilde yapılmakta olan günlük yaşam deneyimlerinin ve duyumlarının fazla olduğu tamirci mesleğini tanıdıkları, isimlendirdikleri, yaptığı işleri bildikleri ve tanımladıkları görülmektedir.

Çocuklara gösterilen imam görseline çoğunlukla bilmiyorum cevabını verdikleri görülmüştür. Ancak çocukların bir bölümü ise hoca olarak isimlendirmişlerdir. Çocukların bu şekilde cevaplandırmalarında toplum içerisinde genellikle imam kelimesi yerine hoca kelimesinin kullanılıyor oluşunun etkili olduğu düşünülmektedir. Benzer bir bulguya futbolcularla ilgili görselde de rastlanılmış, futbolun toplumsal yaşamdaki popülerliğine rağmen çocukların çok az bir kısmı görseldeki kişinin futbolcu olduğunu belirtmiş diğerleri yaptıkları işlerle ilgili farklı cevaplar vermişlerdir. Bu durum belki de çocukların gelişim özellikleriyle açıklanabilecek bir durumdur. Büyüklerin ilgisi olmakla birlikte çocuklar açısından futbol çokta ilgi çekici bulunmuyor olabilir.

Araştırma sonucuna göre çocukların şoför görseline çoğunlukla otobüsçü/dolmuşçu cevabını verdikleri görülmüştür. Çocukların şoförlük mesleğini farklı şekilde isimlendirmelerinde çevresindeki büyüklerinin etkisinin olduğu söylenebilir. Çünkü genelde şoför yerine günlük kullanımda dolmuşçu gibi ifadeler daha yaygın olarak kullanılmaktadır. Ancak çocuklar isimlendirmeyi farklı yapmakla birlikte şoförlerin yaptıkları işleri bildikleri söylenebilir. Araştırmada ilginç olabilecek bir bulgu astronot görseline bağlı olarak çocukların verdikleri cevaplarda görülebilir. Çocukların günlük yaşamlarında karşılaşmadıkları bir konu olmakla birlikte bir grup çocuğun astronotu ismen söylemesi, yarıya yakın oranda çocuğunda uzayla ilgili konulara bağlı cevaplandırmaları, çocukların okul ve televizyon yoluyla bu konuda belirli bir düzeyde bilgiye sahip oldukları görülmektedir.

Araştırmanın bir diğer sonucunda çocuklardan ancak birkaçı eczacı görselini doğru isimlendirebilmişlerdir. Ancak ismi genel olarak bilinmese de çoğunluğunun eczacıların yaptığı işle ilgili olarak genel bir bilgi ve alg1 sahibi oldukları söylenebilir. Bakkal konusunda ise günlük deneyimlere bağlı olarak çocukların tamamına yakınının isim ve bakkalların yaptıkları iş konusunda bilgiye sahip oldukları görülmektedir. Diğer yandan çocukların spiker kavramını bilmedikleri görülmüştür. Çocukların önemli bir bölümü haberci cevabını vererek, yaptığı işi haber sunmak olarak açıklamışlardır. Bu sonuç çocukların spiker mesleğini tanımakta ve isimlendirmekte zorlandıkları ancak yaptığı iş konusunda genel olarak bilgilerinin bulunduğunu düşündürmektedir. 
Araştırma sonucuna göre görsel bir hatırlatıcı sunulmadan sözel olarak sorulan sorulara bağlı olarak çocukların verdikleri cevaplardan, çoğunluğunun hâkimin, psikoloğun, mühendisin, akademisyenin ve YouTuberın yaptı̆̆ işleri büyük oranda bilmedikleri tespit edilmiştir. Benzer sonuçlara Güler ve Akman'ın (2006) yaptığı çalışmada da rastlanmış, çocuklara yönelttikleri bilim insanı kimdir? Bilim insanı ne iş yapar sorularını çocuklar bilmiyorum şeklinde cevaplandırmışlardır. İlgili araştırmalardan farklı olarak Günşen vd. (2019) çocuklardan zihinlerinde yer alan bilim insanı ile ilgili resim yapmalarını istemiş ve çocuklara yaptıkları resimde bilim insanlarının ne yaptıklarını sormuşlardır. Çocukların çoğunluğu bilim insanlarının araştırma/deney yaptıklarını ve uzayı araştırdıklarını ifade etmişlerdir. Ancak elde edilen bulgularda ilginç olan durum, sosyal hayatta daha fazla karşılaşllan ve duyulan mesleklerden olan hâkim, psikolog, mühendis ve akademisyenlerin yaptıkları işlere ilişkin pek bilgiye sahip olmayan çocukların YouTuberın yaptığı işlere ilişkin ise kısmen bilgilerinin olduğunun görülmesidir. Bu durum sosyal medyanın etkisi olarak yorumlanabilir.

Araştırma genel olarak değerlendirildiğinde görülmektedir ki çocukların en çok tanıdıkları ve isimlendirdikleri mesleklerin; öğretmen, doktor, asker, polis, itfaiyeci, çöpçü, kuaför, tamirci ve marketçi/bakkal olduğu görülürken, veteriner, kasap, makinist, pilot, gemi kaptanı, terzi, garson, imam, futbolcu, şoför, astronot, eczacı ve spikerliği ise daha az tanıdıkları ve isimlendirdiklerini söylemek mümkündür. Çocukların kısmen tanıdıkları ve isimlendirdikleri meslekler ise hemşire, aşçı, inşaat işçisi ve şarkıcı olarak saptanmıştır.

Çocukların görseldeki kişinin hangi mesleği yaptığını bilmemelerine ya da görsele farklı cevaplar vermelerine rağmen yaptığı işlerle ilgili fikir ve bilgi sahibi oldukları, yaptığı işi anlamlandırdıkları ve algıladıkları ortaya çıkmıştır. Görseldeki kişinin hangi mesleği yaptığını bilen çocukların o kişinin yaptı̆̆ işlere örnek verdikleri, yaptı̆̆ işleri açıkladıkları ve nitelendirdikleri sonucuna ulaşılmışıır. Çocukların bir kısmı meslekleri yaptıkları işlerle isimlendirmişlerdir. Bu da çocukların mesleklerin isimlerine yönelik kavram yanılg1sı olduğunu göstermektedir. Diğer yandan çocukların hâkim, psikolog, mühendis, akademisyen mesleklerinin yaptı̆̆ işlere ilişkin yeterli bilgilerinin ve farkındalıklarının olmadığı görülmüştür.

Çocukların daha çok iletişime geçtikleri, deneyimlerinin daha fazla olduğu, daha sık karşılaştıkları mesleklere ve meslek gruplarının yaptığı işlere ilişkin düşüncelerini ifade edebildikleri düşünülmektedir. Ayrıca çizgi filmler ve diğer medya araçları çocukların mesleklere, meslek sahiplerinin yaptığı işlere yönelik fikir sahibi olmasına ve farkındalıklarının oluşmasına katkı sağlamış olabilir. Çocukların meslekleri tanımamalarına ve isimlendirememelerine sosyoekonomik düzeyin, yaşanılan yerin, gelişim alanlarındaki yetersizliklerin, aile tutumlarının etkisi olduğu 
düşünülmektedir. Bunun yanı sıra meslekler hakkında bir düşüncelerinin olması ancak doğru isimlendirme yapamamaları mesleki rehberliğin önemini göz önüne getirmektedir. Bu anlamda okul öncesi dönemde çocukların meslekler ve yaptıkları işler konusunda algılarının, bilgilerinin artması, fikir sahibi olması, becerilerinin ve ilgilerinin farkına varılabilmesi için mesleki rehberlik, mesleki yöneltme çalışmalarının başlaması gerekmektedir. Dolayısıyla mesleki gelişim görevlerini yerine getirebilmeleri açısından da oldukça önem taşımaktadır. Ayrıca üniversite tercihi yapacak ya da bir meslek sahibi olan kişilerin dahi bazen meslekleri konusunda kararsızlık, memnuniyetsizlik yaşadıkları dikkate alındığında bu sorunları en aza indirgemek adına okul öncesi dönemde başlayacak olan mesleki faaliyetlerin önemi bir kez daha ortaya çıkmaktadır.

Kişinin uzun yıllar boyunca yapacağı mesleğinin, kendisini olduğu kadar ailesini, çevresini ve toplumu da olumlu veya olumsuz olarak etkilediği bilinmektedir. Bu anlamda mesleklerin çocuklara okul öncesi dönemden itibaren tanıtılması, çocukların meslek gruplarının yaptığı işler konusunda bilgilendirilmesi oldukça önemlidir. Okul öncesi dönemde yapılacak olan etkinliklerin meslekleri tanıtmaya yönelik düzenlenmesi önerilmektedir. Çocuklar mesleklere ilişkin bilgilerinin ve alg1 düzeylerinin artması için somut bir biçimde deneyim yaşamaya gereksinim duymaktadırlar. Çocukların meslek çalışanları ile tanışmaları, yaptığı işleri gözlemlemeleri, şartlar uygunsa o kişilerin meslek kıyafetlerini giymeleri ve aletlerini kullanmaları, üretimde bulunmaları sağlanmalıdır. $\mathrm{Bu}$ doğrultuda alan gezisi ile drama etkinliklerinin yapılması önerilmektedir. Anne ve baba çocuklarının meslekleri öğrenebilmesi, tanıyabilmesi, çocuklarının ilgi, becerilerini keşfedebilmesi için uygun bir ortam oluşturarak onların gereksinimlerine cevap vermeli, meslekleri tanıtmalıdır. Bu araştırmaya beş yaş grubundaki çocuklar katılmıştır. Gelecekte yapılacak araştırmalarda diğer yaş grupları örnekleme dahil edilerek çalışma gerçekleştirilebilir. Öğretmen ve ebeveyn görüşleri alınarak çalışma zenginleştirilebilir. İlgili araştırmada meslek resimleri kullanılmıştır. Yapılacak araştırmalarda mesleklere ait videolar gösterilebilir ya da meslek gruplarını ziyaret ederek deneysel bir çalışma yapılabilir.

\section{KAYNAKÇA}

Aktın, K. (2014). Okul öncesi dönemde sosyal bilgiler eğitimi: mesleklerin öğretimine yönelik bir durum çalışması. Turkish Studies, 9(5), 139-155.

Alabay, E. \& Özdemir, G. (2020). 36-72 aylık çocukların mesleklere yönelik oluşturdukları toplumsal cinsiyet alg1lar1. Turkish Studies, 15(1), 13-29.

Arslan, F., Çağlar, İ. M.\& Gürbıyık, C. (2017). Kültürel miras kapsamında kaybolmaya yüz tutmuş geleneksel meslekler Turgutlu örneği. Studies Of The Ottoman Domain, 7(13), 211-247.

Baltac1, A. (2017). Nitel veri analizinde Miles-Huberman modeli. Abi Evran Üniversitesi Sosyal Bilimler Enstitüsü Dergisi (AEÜSBED), 3(1), 1-15. 
Barclay, L. K. (1974). The emergence of vocational expectations in preschool children. Journal of Vocational Behavior, 4, 1-14.

Best, J. W., \& Kahn, J. V. (2017). Eğitimde araştırma yöntemleri. (O. Köksal, çev.). Konya: Eğitim Yayınevi.

Berg, L. B., \& Lune, H. (2015). Sosyal bilimlerde nitel araştırma yöntemleri. (H. Aydın, çev.). Konya: Eğitim Yayınevi.

Bozgeyikli, H. (2008). Mesleki grup rehberliğinin ilköğretim 8. sınıf öğrencilerinin meslek kararı verme yetkinlik düzeylerine etkisi. Atatürk Üniversitesi Kâžm Karabekir Eğitim Fakültesi Dergisi, 0(18), 36-58.

Byrne, M. M. (2001). Evaluating the findings of qualitative research. AORN Journal, 73(3), 703-706.

Ceylan, Ş., Cevher Kalburan, N., Yurt, Ö., \& Kandır, A. (2009). Uluslararası Mimarlık ve Çocuk Kongresi, 18-21 Kasim, Ankara.

Creswell, J. W. \& Miller, D. L. (2000). Determining validity in qualitative inquiry. Theory Into Practice, 39(3), 124-130.

Çakır, M. A. (2004). Mesleki karar envanterinin geliştirilmesi. Ankara Üniversitesi Eğitim Bilimleri Fakültesi Dergisi, 37(2), 1-14.

Çakmak, Z. (1992). Çoklu Ayırma ve Sinfflandırma Analiz̧i Eğitimde Öğrencilerin Meslek. Seçimine Uygulanması. Eskişehir: Anadolu Üniversitesi Yayınları.

Demir, V., Gürsoy F.\&Ada, Ş. (2011). Okul öncesi öğretmen adaylarının mesleki benlik saygılarının incelenmesi. Gaziantep Üniversitesi Sosyal Bilimler Dergisi, 10(1), 597-614.

Doğan, H. \& Kuzgun, Y. (2008). Bilgi verici danışmanlık programının üniversiteye giriş sınav1 ve üniversite eğitimine ilişkin yanlış inançlara etkisi. Selçuk Üniversitesi Sosyal Bilimler Enstitüsü Dergisi, 0(20), 291-306.

Doyle, S. (2007). Member checking with older women: A framework for negotiating meaning. Health Care for Women International, 0(28), 888-908.

Erkalan, M., Calp, H. M.\& Şahin, İ. (2012). Çoklu zekâ kuramından yararlanılarak meslek seçiminde kullanılacak bir uzman sistem tasarımı ve gerçekleștirilmesi. Bilişim Teknolojileri Dergisi, 5(2), 49-55.

Genç, H.\& Ersoy Alkan, Ö. (2016). Altı yaş çocuklarının gelecekte ne olmak istedikleri üzerine nitel bir çalışma. Kastamonu Eğitim Dergisi, 24(5), 2221-2234.

Guba, E. G. (1981). Criteria for assessing the trustworthiness of naturalistic inquiries. Educational Communication and Technology, 29(2), 75-91.

Güler, T. \& Akman, B. (2006). 6 yaş çocuklarının bilim ve bilim insanı hakkındaki görüşleri. Hacettepe Üniversitesi Eg̈itim Fakültesi Dergisi, 0(31), 55-66.

Günşen, G., Uyanık, G. \& Akman, B. (2019). 5 yaş çocuklarının zihinlerindeki bilim insanı imajı içerisinde Stem alanlarının yer alma durumlarının incelenmesi. Mebmet Akif Ersoy Üniversitesi Eg̈itim Fakültesi Dergisi, 0(52), 320-339.

Hamamc1, Z., Bacanl, F. \& Doğan, H. (2013). İlköğretim Ortaöğretim ve Üniversite öğrencilerinin mesleki ve eğitsel kararlarını etkileyen faktörlerin incelenmesi. Elektronik Sosyal Bilimler Dergisi, 12(44), 284-299.

Hamamcı, Z. \& Esen Çoban, A. (2007). Mesleki olgunluk ve mesleki kararsızlı̆ın akılcı olmayan inançlarla ilişkisi. Türk Psikolojik Danısma ve Rehberlik Dergisi, 3(27), 31-42. 
Karabekmez, S., Yıldırım, G., Özyllmaz Akamca, G., Ellez, A. M. \& Bulut Üner, A. N. (2018). Okul öncesi dönem çocuklarının mesleklere yönelik toplumsal cinsiyet algilarının incelenmesi. Bilim, Eğitim, Sanat ve Teknoloji Dergisi (BEST Dergi), 2(1), 52-70.

Kazi, A. \& Akhlaq, A. (2017). Factors affecting students' career choice. Journal of Research and Reflections in Education, 2, 187-196.

Krefting, L. (1991). Rigor in qualitative research: The assessment of trustworthiness. American Journal of Occupational Therapy, 45(3), 214-222.

Kunduracılar, Z., Akbaş, E., Büyükuysal, Ç., Biçki, D. \& Erdem, E. U. (2012). Fizyoterapi ve rehabilitasyon bölümü öğrencilerinde mesleki farkındalığın değerlendirilmesi. Yükesekögrretim ve Bilim Dergisi, 2(3), 186-192.

Kuzgun, Y., (1999). Illkögretimde Rebberlik (Ed.: Y. Kuzgun), Ankara: Nobel Yayın Dağıtım.

Kuzgun, Y. (2000). Meslek Damısmanlı̆̆ Kuramlar Uygulamalar. Ankara: Nobel Yayın Dağıtım.

Kuzgun, Y. (2002). Rehberlik ve Psikolojik Danısma. Ankara: ÖSYM Yayınları.

Lee, H. C. (2012). What do you want to do when you grow up?" occupational aspirations of Taiwanese preschool children. Social Behavior and Personality, 40(1), 115-128.

Miles, M, B., \& Huberman, A. M. (1994). Qualitative data analysis: An expanded Sourcebook. (2nd ed). Thousand Oaks, CA: Sage.

Millî Eğitim Bakanlığ1 (2012). Okul Öncesi Eğitim Rebberlik Programı. Ankara.

Onat Kocabıyık, O. (2016). Olgu Bilim ve Gömülü Kuram: bazı Özellikler açısından karşılaştırma. Trakya Üniversitesi Ë̆itim Fakültesi Dergisi, 6(1), 55-66.

Özgüven, İ. E. (2001). Çăgdaş Eğitimde Psikolojik Danısma ve Rehberlik.Ankara: PDREM Yayınları.

Pekkaya, M. \& Çolak, N. (2013). Üniversite öğrencilerinin meslek seçimini etkileyen faktörlerin önem derecelerinin AHP ile belirlenmesi. The Journal of Academic Social Science Studies, 6(2), 797-818.

Razon, N. (1983). Meslek seçimi ve mesleğe yöneltme. Eğitim ve Bilim, 8(43), 23-31.

Schultheiss, D. E. P., Palma, T. V. \& Manzi, A. (2005). Career development in middle childhood: a qualitative inquiry. The Career Development Quarterly, 53,246-262.

Temel, M., Bilgiç, Ş. \& Çelikkalp, Ü. (2018). Hemşirelik öğrencilerinin meslek seçiminde etkili faktörler. Yülesekögrretim ve Bilim Dergisi, 8(3), 480-487.

Temiz, Z., Ünlü Çetin, Ş. \& Yılmaz, S. (2020). Okul öncesi eğitim alan beş yaş çocuklarının meslek seçimleri ve cinsiyetlerine ilişkin düşüncelerinin incelenmesi. YYÜ Eğitim Fakültesi Dergisi, 17(1), 318-350.

Trice, A. D. \& King, R. (1991). Stability of kindergarten children's career aspirations. Psychological Reports, O(68), 1378-1378.

Tuzcuoğlu, S. (2000). Benlik ve mesleki benlik kavramlarının öğrenim yılları ile ilişkisi. M.Ü. Atatürk Ë̈̈tim Fakültesi Eğitim Bilimleri Dergisi, 0(12), 267-280.

Ulaş, Ö., Demirtaş Zorbaz, S., Dinçel, E. F., Çiffiliz Kınay, G. \& Coştur, R. (2017). Özel okulda öğrenim görmekte olan lise öğrencilerinin meslek seçimini etkileyen etmenler. Abant İzzet Baysal Üniversitesi Eğitim Fakültesi Dergisi, 17(1), 441-456.

Vurucu, F. (2010). Meslek lisesi ögrencilerinin meslek seçimi yeterliliği ve meslek seçimini etkileyen faktörler. Yayınlanmamış yüksek lisans tezi, Yeditepe üniversitesi, İstanbul. 
Wimpenny, P. (2000). Interviewing in phenomenology and groundedtheory: 1s there a difference?. Journal of Advanced Nursing,31(6), 1485-1492.

Yeşilyaprak, B. (1986). Gençlere meslek seçiminde yapılacak yardımlar. Eğitim ve Bilim, 10(59), 28 32.

Yeşilyaprak, B. (2000). Eğitimde Rehberlik Hiæmetleri. Ankara: Nobel Yayın Dağıtım.

Yıldırım, A. \& Şimsek, H. (2016). Sosyal Bilimlerde Nitel Araștırma Yöntemleri. Ankara: Seçkin Yayınc1lik.

Yılmaz, A. \& Işık Esenay, F. (2020). İlkokul çocuklarının gözünden hemşirelik: Bir ilkokul örneği. Koç Üniversitesi Hemşirelikte Eğitim ve Araștirma Dergisi, 17(3), 252-257.

Yılmaz Erdem, A. \& Bilge, F. (2008). Lise öğrencileri için meslek seçimine ilişkin akılcı olmayan inançlar ölçeğinin geliştirilmesi. Türk Psikolojik Danısma ve Rebberlik Dergisi, 3(29), 95-114.

Yörükoğlu, A. (1998). Cocuk Ruh Sağhğg. İstanbul: Özgür. 